
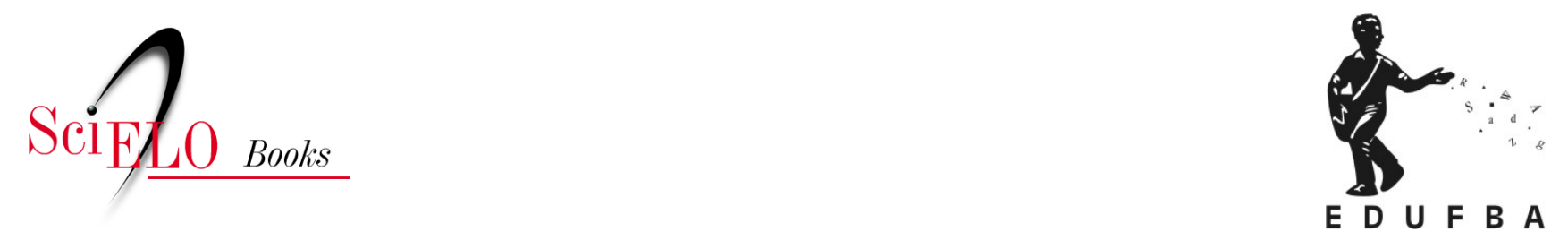

\title{
Gestão do trabalho nos Correios estratégias para construção do consentimento?
}

\author{
Tadeu Gomes Teixeira
}

TEIXEIRA, T.G. Gestão do trabalho nos Correios: estratégias para construção do consentimento? In: Os Correios e as políticas governamentais: mudanças e permanências [online]. Salvador: EDUFBA, 2016, pp. 179-252. ISBN: 978-85-232-2025-9. https://doi.org/10.7476/9788523220259.0007.

All the contents of this work, except where otherwise noted, is licensed under a Creative Commons Attribution 4.0 $\underline{\text { International license. }}$

Todo o conteúdo deste trabalho, exceto quando houver ressalva, é publicado sob a licença Creative Commons Atribição $\underline{4.0}$. 

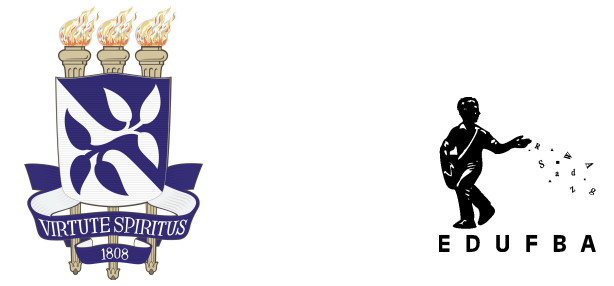

\section{UNIVERSIDADE FEDERAL DA BAHIA}

Editora da Universidade Federal da Bahia - EDUFBA

\section{Att. Scielo}

\section{ERRATA}

Informamos sobre o erro localizado no livro "Os Correios e as Políticas Governamentais: mudanças e permanências":

No capítulo Modernização e reestruturação do modelo industrial de serviços postais da ECT, do livro Os Correios e as Políticas Governamentais: mudanças e permanências, na página 152 onde se lia:

"Figura 15"

leia-se:

"Figura 6"

No capítulo Gestão do trabalho nos Correios, do livro Os Correios e as Políticas Governamentais: mudanças e permanências, na página 207 onde se lia:

"Figura 22"

leia-se:

"Figura 10" 


\section{Gestão do trabalho nos Correios: estratégias para construção do consentimento?}

A política de gestão do trabalho nos Correios foi impactada pelas propostas e mudanças na estatal e também pelas transformações no mundo do trabalho, sobretudo a partir de meados da década de 1990, quando alterações no padrão das relações de trabalho no Brasil foram intensificadas.

Nesse sentido, a adoção de instrumentos remuneratórios que até então não eram comuns no cenário nacional, como os programas de participação nos lucros e resultados (PLR), bem como a revisão de planos de carreiras e salários com o objetivo de permitir maior flexibilidade na gestão da força de trabalho, além de novas demandas advindas das mudanças nos padrões das relações sociais, incluindo as questões de gênero, foram incorporadas às políticas de gestão.

A ECT não esteve alheia a esses processos, que foram incorporados à estatal. Para isso, teve que alterar alguns aspectos de sua política de gestão do trabalho e lidar com novas demandas dos trabalhadores.

Diante disso, neste capítulo são analisadas as políticas de gestão do trabalho na ECT que suscitaram polêmicas entre os trabalhadores e, em razão disso, mobilizaram os gestores, trabalhadores e representantes sindicais a partir da década de 1990.

Os elementos selecionados para análise são a reformulação do plano de cargos, carreiras e salários, a ampliação da terceirização da força de trabalho, as políticas de remuneração, o programa de participação nos lucros e resultados e os aspectos de gênero que perpassam as políticas de gestão, 
além de uma discussão sobre a proximidade entre gestores e sindicalistas a partir do governo de Luís Inácio Lula da Silva. Antes disso, contudo, é apresentado um perfil da força de trabalho dos Correios e a tendência do trabalho no setor em comparação com o cenário internacional.

\section{TRABALHO NOS CORREIOS: CONTRASTE COM O SETOR POSTAL INTERNACIONAL}

A Empresa Brasileira de Correios e Telégrafos, até meados dos anos 2000, era a maior empregadora celetista do Brasil. Nas últimas décadas, apesar de oscilações periódicas, a evolução do número de funcionários na estatal tem sido crescente. Nesse sentido, em 1970, por exemplo, o efetivo somava 64.336 trabalhadores, passando a quase setenta mil em 1990 e alcançando 108.516 funcionários em maio de 2010. Em abril de 2013, depois de processos seletivos em 2011 e 2012, o contingente de funcionários era de 119.971 trabalhadores.

A evolução do emprego nos Correios justifica-se, como destacaram os consultores das missões francesas na década de 1970, pela dependência da área operacional de uma mão de obra direta em suas atividades, sobretudo no setor de distribuição. Entretanto, o setor postal no mundo inteiro é dependente do uso intensivo da força de trabalho. (EIRO, 2007) Assim, não se trata de uma especificidade da estatal brasileira.

$\mathrm{O}$ crescente incremento de profissionais nos Correios ocorreu privilegiando os cargos da área operacional, embora tenha havido um aumento proporcional de funcionários na área administrativa. Assim, mesmo que a área de tratamento tenha passado por uma mecanização e automação da triagem, a ampliação do número de agências e os planos para universalização postal tendem a fomentar o aumento do contingente de trabalhadores.

No entanto, o aumento dos postos de trabalho no setor postal não é uma tendência mundial. De acordo com Dijkgraaf e Van der Zee (2009), o Brasil foi um dos únicos países do mundo onde se constatou o aumento do efetivo no setor postal a partir da década de 1990.

Nesse sentido, verifica-se que na União Europeia trabalhavam 1,94 milhões de pessoas no setor postal em 2006. Contudo, tem havido uma 
enorme mudança nos padrões de trabalho, sobretudo com a redução do número de empregos. (EIRO, 2007)

Nessa direção, é possível observar que na Alemanha, entre 1990 e 2001, o volume de negócios aumentou em 350\%, enquanto um corte em massa de postos de trabalho era realizado no setor. Durante esse período, de acordo com Brandt (2007), a redução foi de 160 mil posições de trabalho. Se for considerado apenas o intervalo entre 1999 e 2006, a redução de empregos em tempo integral foi de mais de 21 mil, ao mesmo tempo em que a redução dos postos com jornada parcial foi de 12 mil. (UNI GLOBAL UNION, 2009) Verifica-se, assim, uma redução drástica do volume de empregos no setor postal naquele país: em torno de 30\%, segundo Dijkgraaf e Van der Zee (2009).

De acordo com Brandt (2007), na Áustria a redução de empregos com tempo integral no Post AG também foi considerável. Se em 2001 esses trabalhadores eram mais de 30 mil, em 2005 eram pouco mais de 25 mil. Segundo a European Foundation For The Improvement of Living and Working Conditions - EIRO (2007), os cortes de empregos na Áustria foram de cerca de $22 \%{ }^{29}$

Na Holanda, a PostNL, por exemplo, reduziu seus funcionários com jornada integral de 20 mil, em 2005, para 16 mil em 2010 e, ao mesmo tempo, ampliou o efetivo com jornada parcial de 6 mil para 13 mil entregadores. (ABVAKABO..., 2011)

O corte de empregos, conforme expõe Brandt (2007), é resultado de medidas de "modernização" para aumentar a competitividade e envolve a flexibilização dos contratos trabalhistas, além dos processos de reestruturação e automação de procedimentos operacionais. ${ }^{30}$

\footnotetext{
29 Os dados de outros países corroboram a tendência mundial de redução de postos de trabalho no setor, segundo o relatório da EIRO (2007), que ainda afirma que houve corte de empregos em torno de 30\% na Noruega, Itália e Malta.

30 Os processos de modernização e reestruturação operacional têm antecedido muitas das liberalizações postais e processos de privatização, como os estudos de caso encomendados pela UNI (2009) evidenciam. Nesse sentido, a automatização de processos, reestruturação dos serviços operacionais e de distribuição, redução de rotas de distribuição e diminuição do número de agências próprias, etc., são estratégias adotadas pelas empresas postais que têm impactado a qualidade e quantidade dos empregos no setor postal em todo o mundo.
} 
A lógica dos países que têm optado por liberalizar o setor postal tem sido modernizar pela automação e reestruturar as atividades operacionais antes da abertura de mercado e, em seguida, adotar medidas para privatização do correio estatal, com a redução de significativos números de empregos em atividades operacionais que antecedem a distribuição postal, como o atendimento em agências e a triagem em unidades intermediárias. (UNI GLOBAL UNION, 2009)

Em escala mundial, os processos de reestruturação estão estreitamente ligados à redução do número de empregos e à precarização, já que alteram o regime de contratação da força de trabalho, que deixa de ser normatizado pelo estatuto do funcionalismo público para ser regido pelo direito privado, cujas consequências têm sido

[...] uma diminuição crescente do poder sindical, uma fragmentação das estruturas de negociação e, por conseguinte, do emprego e das condições salariais dos antigos operadores postais estatais. [...] Em vários setores e países, os novos operadores postais não estão inclusos nos acordos coletivos, sendo beneficiados por normas de empregos inferiores [salários mais baixos e jornadas de trabalho maiores ou mais flexíveis]. (PIQUE apud UNI GLOBAL UNION, 2009, p. 14, tradução nossa)

$\mathrm{Na}$ ECT, o processo de corporatização desvinculou os empregados da estatal da Administração Direta em 1969, com todos os funcionários sendo regidos pela Consolidação das Leis do Trabalho (CLT) desde então. Apesar disso, em decorrência de várias decisões judiciais, os ecetistas têm sido equiparados, para fins de estabilidade, aos funcionários estatutários da Administração Direta. Esse entendimento foi assegurado pela Resolução no. 143/2007 e pela Orientação Jurisprudencial 247 do Tribunal Superior do Trabalho, que declara, ipsis litteris, que

[...] A validade do ato de despedida do empregado da Empresa Brasileira de Correios e Telégrafos (ECT) está condicionada à motivação, por gozar a empresa do mesmo tratamento destinado à Fazenda Pública em relação à imunidade tributária e à execução por precatório, além das prerrogativas de foro, prazos e custas processuais. 
O entendimento dos ministros, portanto, decorre da natureza administrativa da ECT, que possui características de direito público - com o gozo de uma equiparação à Fazenda Pública, o que lhe proporciona os bônus de tal prerrogativa, como isenção fiscal - e de direito privado, com os trabalhadores sendo contratados em regime celetista. Com a resolução do Tribunal Superior do Trabalho, portanto, pacificou-se nos tribunais o entendimento de que os trabalhadores da ECT têm direito à estabilidade profissional contra a dispensa imotivada, sendo necessário processo administrativo antes de quaisquer atos de demissão. Com isso, os ecetistas estão em um lugar entre o direito público e o privado. Dessa maneira, o processo de corporatização da ECT, que garantiu até 1988 a livre contratação e demissão dos trabalhadores ecetistas, foi reinterpretado, garantindo relativa estabilidade no emprego, mesmo com os contratos de trabalho sendo regidos pela CLT.

$\mathrm{O}$ aumento do número de trabalhadores da empresa mostra, por outro lado, que o setor no Brasil demanda a crescente incorporação de trabalhadores e que a diretriz do governo federal na última década tem sido, de maneira geral, pela contratação de empregados. Orientação bem distinta da tendência internacional de redução dos postos de trabalho no setor postal.

Para repor o pessoal necessário à execução das atividades postais, tem se observado na União Europeia o aumento de contratos de trabalho que priorizam a flexibilidade do vínculo trabalhista, como o trabalho por turnos e escalas e também a jornada parcial (part-time). (EIRO, 2007)

A maioria dos novos postos de trabalho criados pelas empresas postais privadas no cenário internacional tem sido de contratos de trabalho precários e atípicos, o que inclui o trabalho autônomo em agências de atendimento franqueadas. Trata-se, portanto, de um claro processo não só de redução do volume de empregos no setor como também de precarização do trabalho. $O$ processo de precarização das condições de trabalho tem aumentado também pela intensificação do trabalho para os trabalhadores que permaneceram nos empregos, o que explica o fato de alguns países, como a Dinamarca, encontrarem problemas para atrair e reter trabalhadores no setor postal. (EIRO, 2007) 
Em relação à educação e qualificação dos trabalhadores, a partir da segunda metade da década de 1990 a ECT incentivou o aumento do nível formal de instrução de seus funcionários por meio de medidas corporativas para promoção da escolaridade e pelo aumento dos níveis de escolaridade dos candidatos em concursos. Esse último aspecto pode ser exemplificado pela seleção para o cargo de carteiro, que passou a exigir o Ensino Médio dos candidatos no final da década de 1990. Até então, os concursos de admissão ao cargo exigiam somente o Ensino Fundamental. Da mesma maneira, o cargo de operador de triagem e transbordo - que até então só necessitava do primeiro ciclo do ensino primário - passou a exigir dos candidatos o Ensino Médio, o que só era exigido dos atendentes comerciais.

A mudança pode ser apreendida nos números sobre a escolaridade da força de trabalho. Se em 1996 apenas 56\% da força de trabalho possuíam formação de nível médio, em 2004 o índice era de 75\%. Já em 2010, no entanto, 3\% da força de trabalho tinham até o Ensino Fundamental, 75\% o Ensino Médio e 21\% o Ensino Superior. Os empregados com formação universitária estavam distribuídos por cargos de nível básico (0,9\% do total de cargos), médio (94,15\%), e superior (4,93\%). Assim, os dados mostram, principalmente, que atualmente há nos Correios uma força de trabalho - pelo menos 16,07\% dos ocupantes de cargos de nível médio - que prestou concurso para cargos de nível médio, mas que possuem, ou obtiveram, formação universitária. Dessa maneira, apura-se que os esforços para aumentar a formação da força de trabalho incrementaram a escolaridade dos trabalhadores. Dessa forma, verifica-se que a ECT seguiu a tendência constatada por Rachid e Gitahy (1995) acerca da correlação entre a crescente demanda por aumento da escolaridade e qualificação dos trabalhadores concomitante aos processos de reestruturação.

Além disso, os Correios implantaram, durante a década de 1990, programas de qualidade total voltados para a "excelência empresarial", como " 5 ", treinamento no local de trabalho, de melhoria contínua etc. (BARROS NETO, 2004) Tais programas, como destacaram Araújo, Cartoni e Justo (2001), ocorreram na década de 1990 em segmentos distintos, como no setor bancário e metalúrgico, e seguem a tendência dos processos de reestruturação produtiva durante a década de 1990, associando 
transformações dos processos produtivos às transformações nas políticas de gestão do trabalho.

\section{DESENHO DE CARREIRAS E HIERARQUIA FUNCIONAL: A TENSÃO PERMANENTE}

Ao estudar processos de reestruturação produtiva nas décadas de 1980 e 1990 no Brasil, Gitahy (2000) constata que a reformulação e criação de planos de carreiras, cargos e salários foi uma das estratégias empresariais para introduzir, inclusive no "chão de fábrica", cargos com características multifuncionais.

Os Correios em 1995 reformularam ${ }^{31}$ o Plano de Cargos, Carreiras e Salários (PCCS). Com o novo PCCS, houve a formalização do desenho dos cargos e a divisão das atividades operacionais em carreiras de carteiros, operadores de triagem e transbordo e atendentes comerciais. Uma inovação apresentada no novo plano foi a criação de níveis de progressão funcional para os cargos. Assim, por exemplo, estabeleceram-se critérios para a progressão de carteiro I para II e III. Obviamente, não se trata de uma mudança de cargo ou função profissional, mas tão somente do estabelecimento de níveis para progressão na carreira. O principal critério para progressão e mudança de nível é o tempo de exercício no cargo. Com a mudança de nível, o funcionário passa a receber um percentual de acréscimo ao salário.

Os cargos de nível superior eram preenchidos por seleção externa, realizada para carreiras específicas, como médico, contador, advogado, administrador etc. A progressão era semelhante aos cargos operacionais, embora com outra denominação, isto é, júnior, pleno e sênior.

Não havia a possibilidade dos funcionários operacionais mudarem de carreira pelo PCCS de 1995. As possibilidades de mudança centravam-se somente nas funções, para as quais havia a possibilidade de uma indicação da chefia ou participação em um processo de recrutamento interno.

31 No capítulo 2 discutiu-se o impacto da corporatização da ECT na reformulação do plano de cargos, carreiras e salários em 1974 - quando findaram os funcionários estatutários - e em 1987, quando os cargos de carteiro foram unificados. 
Carteiros motorizados, por exemplo, eram considerados em exercício de uma função gratificada, seja para pilotar motos ou veículos. Não se tratava, assim, de uma alteração no conteúdo da atividade de trabalho, mas nos meios de executá-las.

Já em relação à ascensão, um funcionário que entrasse como carteiro na empresa só teria a possibilidade de exercer outras atividades como, por exemplo, a gestão de uma unidade operacional, caso fosse indicado como supervisor operacional ou participasse de um processo de recrutamento interno. Caso quisesse acessar a carreira de administrador, no entanto, teria que participar de seleção externa - mesmo que tivesse os requisitos necessários. Em outras palavras, os cargos tinham uma concepção de carreira inerente às suas atividades.

O PCCS de 1995 passou a ser considerado desatualizado pela ECT diante das transformações por que a empresa e o país passaram ao longo da década de 1990 e anos 2000. Com isso, a estatal passou a envidar esforços para reformular sua estrutura de cargos e carreiras já no início do governo Lula. A FENTECT buscou assegurar participação na formulação do novo plano de cargos e carreiras, tendo, para isso, incluído a partir de 2003 (até 2008) cláusulas no acordo coletivo de trabalho que garantiram a participação dos representantes dos trabalhadores nas negociações.

O PCCS em formulação, inicialmente denominado de Sistema de Carreira e Remuneração, em meados de 2005 já dispunha de uma versão que apresentava como uma de suas premissas "uma maior flexibilidade ao gerenciamento e à mobilidade da força de trabalho dentro da estrutura da Empresa", o que, em tese, poderia "garantir maiores oportunidades de ascensão funcional, por meio de recrutamentos internos para mudanças de atividades e para ocupação de funções nas áreas gerenciais e técnicas." (EVOLUÇÃO..., 2005) A possibilidade de ascensão, evidentemente, é algo almejado pelos trabalhadores, embora os mecanismos propostos pela empresa tenham sido questionados - como será analisado adiante.

No início de 2008, depois de anos de debates e discussões, a ECT e a FENTECT acordaram alguns pontos, embora as negociações fossem se intensificar a partir de então. A FENTECT considerou insuficiente a proposta 
da ECT e formulou um "PCCS dos Trabalhadores" para orientar as negociações com a estatal e comunicar suas ideias aos trabalhadores. Segundo a FENTECT, em cartilha distribuída aos trabalhadores e intitulada "O que é esse PCCS?”, "A responsabilidade pela elaboração do PCCS é da empresa. Entretanto, a ECT apresentou uma proposta à nossa categoria que não atende aos nossos interesses". Com base nisso, a Federação propôs alguns caminhos para um "PCCS do trabalhador".

Em primeiro lugar, defendeu a criação da "Carreira de Correios e Telégrafos" para cargos que exercem as atividades de nível médio e destinadas às atividades finais da empresa, como distribuição, atendimento, transporte, trabalhos em unidades operacionais etc. Ao mesmo tempo, seria criada uma "Carreira de Suporte de Correios e Telégrafos" - destinada a abarcar os trabalhadores envolvidos indiretamente com as atividades finais da estatal. O ingresso nas carreiras seria por seleção externa destinada aos postulantes com Ensino Médio completo e realizada por atividades - distribuição, atendimento, tratamento. A partir do ingresso nas carreiras, os funcionários de nível médio teriam a possibilidade de ascensão por meio de recrutamentos internos destinados à mesma carreira e atividades. Assim, funcionários da Carreira de Correios e Telégrafos - atividade carteiro poderiam ascender ao cargo de Técnico de Distribuição e chegar ao topo da carreira na função de Administrador Postal de Distribuição. Para a carreira de atendimento, o mesmo procedimento: ingresso na atividade como atendente comercial, ascensão ao cargo de Técnico de Atendimento e Vendas e, finalmente, Administrador Postal Comercial.

Seriam criadas, portanto, carreiras fechadas pela proposta da FENTECT, isto é, sem a possibilidade de um trabalhador de uma atividade específica executar tarefas distintas. Assim, um funcionário da atividade "carteiro" não poderia exercer a atividade de tratamento e transbordo ou atendimento e vendas, e vice-versa. Para os cargos de nível superior, seriam criados cargos e carreiras específicas, com gradações e promoções baseadas na antiguidade. Em relação aos salários, eles seriam baseados em referências salariais anuais, isto é, para cada ano em exercício no cargo o funcionário receberia uma referência salarial. Dessa maneira, seriam 35 referências salariais por cargo e carreira. 
A proposta da FENTECT apresentada no PCCS baseava-se em uma crítica às primeiras propostas da ECT que - na percepção da entidade sindical - favoreceriam somente os funcionários de nível superior, apresentavam critérios insuficientes para garantir a ascensão funcional e propunham uma avaliação de desempenho baseada em comportamentos, e não só em resultados, além de outras críticas pontuais.

Um dos principais argumentos e críticas da FENTECT - e isso explica sua ênfase na proposição de carreiras definidas - focalizava o conceito de "cargo amplo" que a ECT pretendia implantar. O cargo amplo ancorava-se no conceito de multifuncionalidade e preconizava a possibilidade de um funcionário que prestou concurso para atividade de distribuição, por exemplo, ser alocado em atividades de atendimento e vendas. Seria uma forma de flexibilizar os cargos dos trabalhadores da área operacional, deslocando-os conforme as necessidades de trabalho e garantindo maior flexibilidade com base na institucionalização e aprofundamento da multifuncionalidade. Com isso, cargos de carteiro, atendente comercial e operador de triagem e transbordo deixariam de existir com a criação do cargo de Agente Postal - cargo único da carreira de nível médio da empresa.

Durante o ano de 2007, além de formular e apresentar a sua proposta de PCCS por meio da comissão instituída para essa finalidade, a FENTECT e a ECT reuniram-se inúmeras vezes para debater o assunto - não logrando muitos êxitos. A FENTECT argumentava que a empresa tentara em muitas ocasiões apenas informar a proposta a ser implantada, sem levar em consideração as proposições da entidade. Em um de seus últimos informes de 2007 (Informe 009 da Comissão de PCCS), a FENTEC afirmou que a ECT aparentava querer protelar as negociações, desconsiderando as propostas da entidade sindical.

Em linhas gerais, esse era o cenário das propostas e argumentos da FENTCT no início de 2008, quando muitas reuniões ocorreram sem que se obtivesse um consenso entre a Federação e a ECT sobre os principais pontos em discussão. Dentre tais pontos, podem-se destacar os seguintes: sistema de salários; sistema de carreiras e critérios para progressão funcional; concepção dos cargos (se multifuncional, em caso de aprovação do "cargo amplo"); reposição de perdas de funcionários de cargos extintos etc. 
Entre os meses de fevereiro e julho de 2008, as negociações entre FENTECT e ECT foram improdutivas, levando a Federação a aprovar indicativo de greve no congresso geral da categoria. A deflagração de greve foi marcada para $1^{\circ}$ de julho - mesma data em que a ECT implantou o PCCS. A greve não teve como motivo apenas as negociações do PCCS, mas também um embate em torno de um adicional de risco e do pagamento da PLR de 2007, mais precisamente o não cumprimento de um acordo para redistribuição dos valores.

A greve se estendeu por vinte dias, encerrando-se em 21 de julho. Seu término, no entanto, não foi decorrente de um acordo entre as partes, mas da instauração de um dissídio coletivo a pedido da ECT no Tribunal Superior do Trabalho, considerando a greve "abusiva". O Tribunal intermediou e homologou acordo estabelecido entre as partes que, em linhas gerais, estabelecia o fim da greve, a não punição aos grevistas e a compensação dos dias parados por meio de um banco de horas até a distribuição total das correspondências acumuladas, o pagamento dos dias parados com respectivos benefícios e, principalmente, o pagamento dos adicionais de distribuição aos carteiros: adicional de atendimento em guichês no valor correspondente a $30 \%$ do salário-base aos funcionários em efetivo exercício de tais atividades. ${ }^{32}$

Além disso, ficou acordado que as negociações em torno do PCCS 2008 implantado pela ECT seriam reabertas por um prazo de noventa dias para tratarem das cláusulas em disputa e, a partir disso, o que não fosse acordado seria julgado pelo Tribunal. Pelo balanço da Federação, o movimento grevista foi positivo porque garantiu a manutenção do "Adicional para os carteiros" e "a suspensão do PCCS/2008 de 01 de julho, implantado unilateralmente pela direção da ECT", além de também conseguir a "continuidade das negociações do PCCS/2008 com prazo estipulado." (FENTECT..., 2009d)

A partir da decisão homologada pelo Tribunal Superior do Trabalho, as negociações centraram-se, portanto, em torno do PCCS. Mesmo com um prazo inicial de noventa dias, a ECT e a FENTECT apresentaram os pontos

32 Os adicionais serão detalhados na próxima seção. 
acordados do PCCS 2008 ao TST somente um ano depois, em 29 de junho de 2009. Mesmo assim, houve divergência entre alguns sindicatos da categoria e a Comissão de PCCS da FENTECT - que tentaram rever o acordo e foram impedidos de participar como partes interessadas do julgamento no Tribunal, alegando que divergências entre a categoria deveriam ser discutidas no âmbito dos congressos sindicais. Não obstante, em agosto de 2010 o TST proferiu sua decisão acerca do PCCS, levando em consideração, principalmente, os pontos já negociados e acordados entre as partes. Trata-se de um dos raros casos na jurisprudência brasileira de negociações de planos de carreiras negociados e decididos pela Justiça do Trabalho.

De acordo com a Minuta de Atualização do PCCS de 2008, as características orientadoras do plano de carreiras a ser implantado estabeleciam, dentre suas características norteadoras, o foco em competências e resultados; uma descrição dos cargos que enfatiza a sua missão e atribuições essenciais; carreiras estruturadas em estágios de desenvolvimento; avaliação de desempenho focada na aplicação de competências vinculadas a resultados e salários; e benefícios integrados e complementares.

As orientações técnicas adotadas pela empresa levaram em consideração os seguintes pontos:

- cargos da carreira de nível médio desdobrados em atividades, ensejando à Empresa melhor gerenciamento da sua força de trabalho e assegurando ao empregado a possibilidade de planejamento de sua carreira;

- cargos das carreiras de nível superior e de cargos específicos, além do Técnico de Correios, desdobrados em estágios de desenvolvimento Júnior, Pleno e Sênior, possibilitando ao empregado a oportunidade de crescimento na carreira;

- definição da missão dos cargos e descrição concisa das atribuições essenciais que compõem cada um dos cargos;

- desenvolvimento na carreira com a evolução funcional e profissional e possibilidade de evolução salarial do empregado;

- estruturação de salários de modo que mantenha a coerência interna, expressa pela hierarquia dos cargos e a coerência externa, representada pelo mercado de salários, inclusive com a adoção de adicionais de remuneração, quando couber. (ECT, 2008) 
Tais orientações resultaram na formulação de carreiras definidas para cargos de nível médio, nível superior e cargos específicos. As carreiras de nível médio foram desdobradas em atividades, enquanto a carreira de nível superior ficou com atribuições e especificações de Analistas de Correios. Os cargos de Técnico em Correios, Analista de Correios e cargos específicos foram contemplados com estágios de desenvolvimento.

Com base nessas orientações, a carreira de nível médio foi estabelecida para Agente de Correios (cargo de ingresso por seleção externa) no exercício de atividade de carteiro, operador de triagem e transbordo, atendente comercial e suporte. Em seguida, o cargo de Técnico de Correios com estágios de desenvolvimento júnior, pleno e sênior e correspondente às atividades operacional, comercial e suporte. Finalmente, o último estágio da carreira de Agente de Correios foi estipulado para o Especialista Postal nas respectivas atividades, isto é, operacional, comercial e suporte. No cargo de nível médio, portanto, a FENTECT conseguiu uma solução negociada contra o "cargo amplo" e obteve a separação dos cargos e carreiras, como em sua proposta inicial. Com isso, houve uma convergência entre a proposta da Federação e o desenho de cargos de nível médio adotado pela ECT.

Com isso, a arquitetura da carreira de nível médio passou a ter a seguinte configuração:

FIGURA 8-ARQUITETURA DA CARREIRA DE NÍVEL MÉDIO

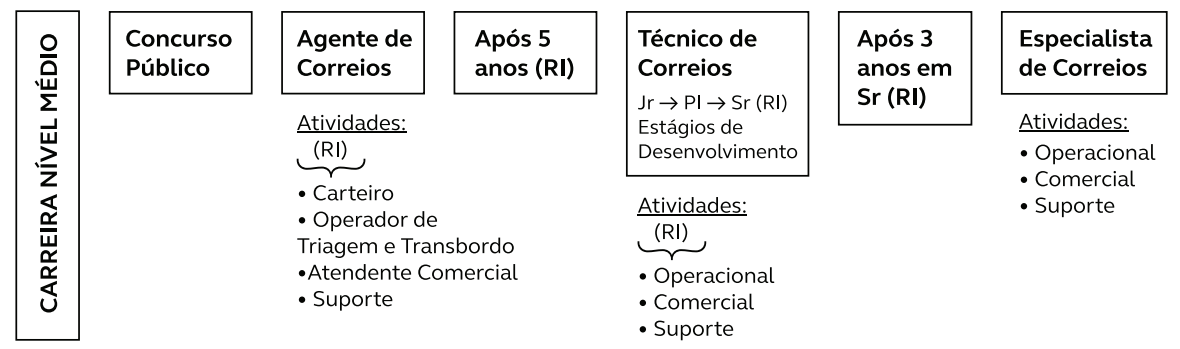


É preciso atentar que a progressão na carreira de nível médio foi condicionada à antiguidade no cargo e à participação em um processo de Recrutamento Interno (RI), cujas regras não foram acordadas na ocasião de assinatura do acordo em 2008, nem em 2009.

A carreira de nível superior destinada aos Analistas de Correios também foi seccionada em estágios de desenvolvimento (júnior, pleno, sênior e máster) e distribuída em especialidades como administração, advocacia, psicologia, medicina, assistência social, análise de sistemas, engenharia etc. Por fim, cargos de carreira específica foram desdobrados em especialidades, abarcando o nível médio e superior; são carreiras que não se relacionam diretamente com as atividades finais da estatal.

A arquitetura da carreira de nível superior e de cargos específicos ficou com a seguinte configuração:

FIGURA 9-ARQUITETURA DAS CARREIRAS DE NÍVEL SUPERIOR

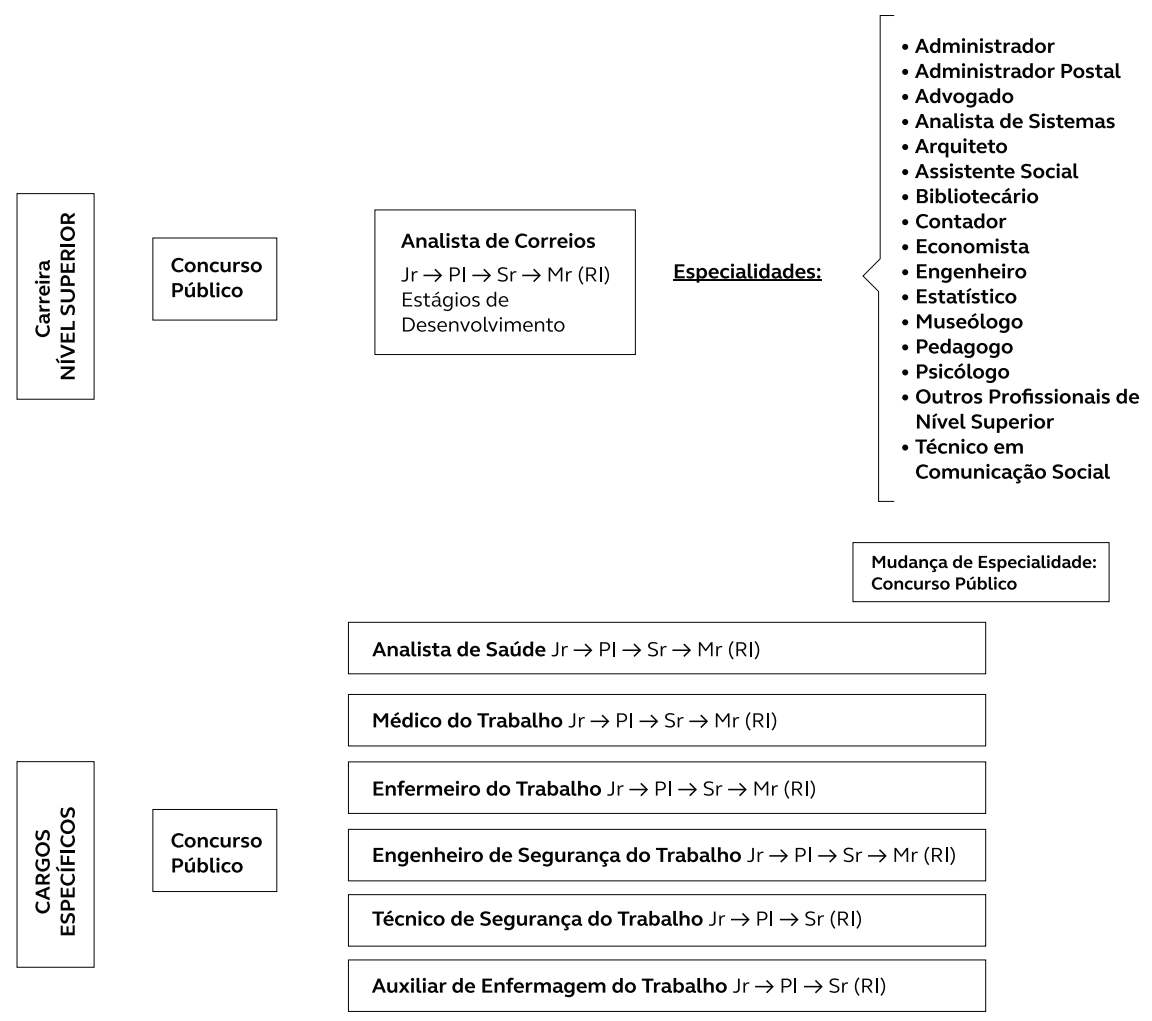


Assim como no caso da carreira de Ensino Médio, os ocupantes de cargos de nível superior e cargos específicos também têm que passar por um Recrutamento Interno para progredirem na carreira. As formas de progressão foram definidas em horizontais e verticais. As progressões horizontais são orientadas por mérito e antiguidade na carreira. As promoções são definidas por mudança de cargo ou estágio de desenvolvimento na carreira.

A promoção vertical do cargo de Agente de Correios, segundo a arquitetura de carreiras, conduz tais funcionários ao cargo de Técnico de Correios no estágio de desenvolvimento júnior. Para isso, no entanto, o Agente de Correios precisa estar em seu cargo há pelo menos cinco anos e participar de processo seletivo por meio do Recrutamento Interno - quando houver vagas. Quando no cargo de Técnico de Correios, a ascensão para Especialista em Correios está condicionada à permanência do funcionário no cargo por cinco anos e é necessário apresentar avaliação de desempenho adequada, dentre outros especificações.

As progressões profissionais nos estágios de desenvolvimento da carreira estão condicionadas aos critérios como antiguidade e Recrutamento Interno. As progressões horizontais que repercutem em ganhos salariais também contemplam a antiguidade dos funcionários, o que explica a existência de trabalhadores exercendo as mesmas atividades, mas auferindo remunerações diferentes.

Cabe destacar, finalmente, que a mudança de atividade para ocupantes de cargos de nível médio, isto é, de Agentes de Correios, ocorre sempre dentro da carreira de nível médio. Para isso, o funcionário precisa estar no cargo há pelo menos três anos e atender a outros critérios estipulados pela ECT. Além disso, a mudança de atividade pelo Agente Postal resulta na alteração do contrato de trabalho - é preciso assinar novo contrato adequado ao cargo. Além das condições especificas até o momento, a ECT determinou que a regulação dos Recrutamentos Internos seria realizada e apresentada oportunamente nos manuais de gestão da empresa..$^{33}$

33 Em janeiro de 2012 ainda não havia sido finalizado nenhum processo de Recrutamento Interno, razão pela qual não é possível analisar e apresentar detalhadamente os critérios que seriam utilizados pela empresa. 
A comparação entre os PCCS de 1995, a primeira versão de 2008 e os ajustes realizados permite verificar as seguintes alterações em alguns dos temas mais polêmicos nas negociações:

a) Cargo Amplo: pelo PCCS de 1995, o "cargo amplo" se tornou uma possibilidade no sistema de carreira. No entanto, sua operacionalização ocorreu apenas em campanhas promocionais e venda de produtos, sem se constituir em mecanismo de realocação de mão de obra. Em 2008, a ECT buscou instituir a multifuncionalidade dos Agentes de Correios nas diversas atividades operacionais, com livre realocação dos trabalhadores. Com o andamento das negociações, a FENTECT conseguiu impedir a implantação da multifuncionalidade.

b) Arquitetura de Carreira: no PCCS de 1995 os cargos eram "carreiras" com estágios de desenvolvimento, como no caso dos carteiros, cuja carreira era definida pela progressão de carteiro I para II e III, sendo a mudança de cargos viável somente por meio de seleção externa. A proposta da ECT com o PCCS de 2008 preconizava a mudança de atividade do Agente de Correios sem alterar a situação do funcionário. A ascensão na carreira de nível médio se daria pela progressão para o cargo de Técnico em Correios e Especialista em Correios por meio de participação em Recrutamento Interno. Com as negociações, a FENTECT e a ECT chegaram ao acordo de manter o cargo de Agente de Correios com atividades específicas, sem instituir o cargo amplo. Outro ponto considerado favorável pela FENTECT foi a possibilidade dos funcionários administrativos terem uma carreira por meio da ascensão em suas atividades.

c) Demissão por baixo desempenho: no PCCS de 1995 e no de 2008 a ECT propunha a demissão de funcionários com baixo desempenho, que seria averiguada - a partir de 2008 - pelo Gerenciamento de Competências e Resultados. A proposta da estatal apresentava dois períodos de avaliação de baixo desempenho para que o funcionário fosse acompanhado pela chefia imediata - que faria a avaliação final e recomendaria a demissão. Tal possibilidade foi rejeitada pela FENTECT e o ponto foi suprimido do PCCS, o que foi considerado uma vitória pela Federação.

d) Jornada de trabalho diferenciada: a ECT buscou instituir em $1995 \mathrm{e}$ em 2008 o banco de horas; a proposta foi rejeitada pela FENTECT e ficou acordado que o mecanismo não faria parte do PCCS. 
e) Promoção horizontal por mudança de atividade: em 1995 não havia a possibilidade de mudança de atividade, exceto por concurso público (seleção externa). Em 2008, a empresa buscou criar um mecanismo para viabilizá-la, sem que ele implicasse em transposição do cargo ou acréscimo salarial. Houve a recusa da proposta pela Federação e acordou-se que seria possível aos funcionários voluntariamente mudarem de atividade por meio de Recrutamento Interno.

Esses foram alguns dos pontos convergentes das negociações entre a FENTECT e a ECT. No entanto, havia o impasse em relação a diversos outros aspectos que continuaram a ser negociados no Tribunal Superior do Trabalho, até que este proferisse a decisão final.

Segundo o acórdão do TST, a ECT cedeu em aspectos que possibilitaram a realização do acordo, embora não tenha sido em todos os termos. Em relação a isso, a posição do Tribunal focalizou a impossibilidade do órgão dirimir conflitos resultantes de negociações trabalhistas com a empresa, sobretudo porque alguns seriam de competência privativa ao poder administrativo da ECT. Nos termos do Tribunal:

Nota-se que as reivindicações da Federação sequer estariam incluídas dentro das prerrogativas do Poder Normativo da Justiça do Trabalho, caso a questão fosse efetivamente levada a julgamento com análise individualizada dos pontos controversos, por serem questões afetas privativamente à esfera administrativa da empresa. (FENTECT, 2011)

No mesmo sentido, o Ministério Público do Trabalho reiterou a posição do Tribunal Superior do Trabalho, afirmando que

escapa ao Poder Normativo da Justiça do Trabalho conceder benefícios relativos a Plano de Cargos e Carreiras, porquanto somente pela negociação direta entre as partes tal pode ser conquistado. Segundo entende, - a implantação do Plano de Cargos, Carreira e Salários - 'PCCS acarreta pesados ônus financeiros aos cofres dos empregadores, o que exige solução autônoma das partes envolvidas.' (BRASIL, 2011)

Com base nisso, o Tribunal proferiu sua sentença em agosto de 2010, reiterando a validade dos acordos estabelecidos entre a FENTECT e a ECT em relação ao PCCS de 2008 e suas alterações, além de acrescentar pontos 
pacificados em relação aos adicionais de atividade. Antes, contudo, de tratar dos adicionais, é importante situar os pontos de divergência que não obtiveram uma solução negociada e que a Justiça do Trabalho afirmou não ter prerrogativa para normatizar. São os seguintes:

[...] subsistema de remuneração, manutenção da progressão de incentivo escolar (PIE) por tempo indeterminado; incorporação do diferencial de mercado para todos os trabalhadores; garantia de vantagens para todos os trabalhadores que permanecerem no PCCS/1995; discussão com a FENTECT de toda e qualquer alteração do PCCS; jornada de trabalho diferenciada, garantia dos direitos do PCCS/2008 para os trabalhadores que não optarem pelo reenquadramento em função de inovações tecnológicas ou racionalização de processos, supressão do adicional de atividade estratégica; inclusão da atividade de motorista no cargo de agente de correios; apresentação de critérios para recrutamento interno, matriz de desenvolvimento, dimensionamento de pessoal e avaliação de desempenho para a progressão funcional; adicional de risco; discussão do item 8.11 (enquadramento no cargo de agente de correios - atividade suporte); manifestação do não aceite do trabalhador; corrigir a redação do item 8.9.1 (adicional de atividade externa). (BRASIL, 2011)

Desses pontos em aberto, cabe destacar a tentativa por parte da FENTECT em garantir os direitos dos funcionários que não aderiram ao PCCS de 2008. No entanto, ficou entendido que apesar de não constar no PCCS de 2008, os funcionários que não aderissem ao novo plano não teriam perdas de direitos. Entretanto, como forma de forçar a adesão de todos os trabalhadores, a ECT estabeleceu que somente os funcionários optantes pelo novo plano de carreiras poderiam participar, por exemplo, dos recrutamentos internos e usufruir das novas regras.

Em relação à progressão de incentivo escolar (PIE), é importante destacar que tal benefício consiste na concessão de uma referência salarial aos funcionários dos níveis básico e médio que obtivessem um nível educacional acima do exigido para o cargo. Assim, por exemplo, se em meados dos anos 2000 para ingresso na carreira de carteiro (pelo PCCS de 1995) a exigência era de Ensino Médio, o funcionário com nível universitário recebia uma referência salarial como política de incentivo à educação - a referência salarial do PCCS 1995 correspondia 5\% do 
salário-base. O plano da ECT era acabar com o PIE já em 2008, mas pelos acordos com a FENTECT estendeu o prazo para que os funcionários solicitassem o benefício até 2011. O PIE foi um mecanismo de incentivo educacional aos trabalhadores do nível fundamental e médio acionado a partir de 1997 para incentivar a progressão educacional. Deixou, portanto, de ser fundamental em um contexto em que os funcionários da empresa, em sua maioria, apresentam níveis adequados ao cargo ou mesmo superiores aos objetivos da empresa.

Apesar das polêmicas e tensas negociações, houve importantes incrementos na remuneração dos trabalhadores, principalmente com o embate em torno de um possível adicional de periculosidade que seria concedido aos carteiros. A proposta inicial para concessão de adicional de periculosidade aos carteiros foi apresentada pelo senador Paulo Paim por meio do Projeto de Lei no. 7362/2006 - que buscava alterar a CLT, incluindo a atividade de carteiro como "perigosa". De acordo com o relator da proposta na Câmara dos Deputados, os carteiros correm riscos em suas atividades externas de distribuição postal como, por exemplo, assaltos, atropelamentos, doenças cutâneas e ortopédicas, o trabalho em condições climáticas adversas e variadas etc. Além disso, os acidentes de trabalho envolvendo carteiros correspondiam, à época, a 9,7\% dos casos informados ao Ministério do Trabalho e Emprego. (CÂMARA..., 2007)

A proposta foi aprovada nas duas casas legislativas. No entanto, o presidente Lula vetou a proposta pela mesma apresentar "contrariedade ao interesse público" (Diário Oficial da União, 20/11/2007. Seção 1, p. 41). Cabe ressaltar que esta não era a primeira vez que um projeto para concessão de periculosidade aos carteiros era vetado, pois o mesmo havia acontecido no segundo mandato do presidente Fernando Henrique Cardoso. Além disso, já no acordo coletivo de 1988 as partes firmavam que "O pagamento, pela ECT, de adicional de atividades penosas fica condicionado à regulamentação do Art.70, Inciso XXIII, da Constituição Federal, nesse sentido" (Cláusula 16, Acordo Coletivo 1988). Em outras palavras, já era histórica a reivindicação da categoria pela incorporação das atividades postais como "penosas", o que tinha por objetivo alcançar o acréscimo de 30\% aos salários, além de benefícios previdenciários mais favoráveis. 
$\mathrm{O}$ veto do presidente Lula à proposta desencadeou generalizada insatisfação na categoria que, por meio da FENTECT, buscou negociar com a ECT o pagamento de um adicional correspondente aos $30 \%$ pagos aos profissionais que exercem atividades insalubres e penosas. As negociações avançaram e o acordo foi obtido já para o mês de dezembro de 2007 por meio de um "abono emergencial" a ser pago nos três meses seguintes e transformado, a partir de março de 2008, em "adicional de risco" destinado aos funcionários em exercício de atividades externas em efetivo exercício. Com isso, o governo federal atendia à incorporação de um adicional aos salários dos carteiros sem instituir uma regra na legislação.

Em março de 2008, no entanto, a ECT não havia apresentado os mecanismos para incorporação do adicional de risco definitivamente aos salários dos carteiros, o que levou a FENTECT a conclamar uma greve em defesa do adicional, contra os critérios de distribuição da PLR e pela negociação de um PCCS mais adequado aos trabalhadores. A greve, que se estendeu por uma semana, foi a primeira das três que ocorreram em 2008 e resultou na prorrogação do "abono emergencial" por mais noventa dias. Apesar do término da greve, os carteiros permaneceram em estado de greve pelo cumprimento do acordo e pela incorporação definitiva do adicional aos salários.

Com as decisões e negociações em torno do PCCS 2008, a empresa propôs a inclusão de adicionais não só para os carteiros, mas também para os atendentes comerciais e operadores de triagem e transbordo.

O acordo foi possível depois de intensas negociações entre 2008 e 2010, sendo intermediado pelo Tribunal Superior do Trabalho. Com isso, foi incorporado ao PCCS o "adicional de risco" - transformado em Adicional de Atividade de Distribuição e Coleta para os carteiros, correspondendo a 30\% do salário básico.

Os funcionários das agências dos Correios, por sua vez, foram contemplados com o Adicional de Atendimento em Agências de Correios (AAG), enquanto os agentes de correios na atividade de operador de triagem e transbordo receberam o Adicional por Atividade de Tratamento (AAT). Na ocasião, os valores não foram superiores a $\mathrm{R} \$ 146,00$ (cento e quarenta e seis reais), reajustáveis conforme o índice de reajuste salarial definido nos acordos coletivos. 
Outros conflitos importantes nesse período relacionaram-se à questão da terceirização da força de trabalho, que abordaremos a seguir.

\subsubsection{Terceirização da força de trabalho: conflito e judicialização}

As transformações nas relações e condições de trabalho no setor postal internacional alteraram o vínculo dos trabalhadores com as empresas do setor. De forma geral, as principais consequências para os trabalhadores referem-se à redução dos empregos, à precarização do trabalho com o deslocamento do regime de trabalho para jornadas parciais e o aumento de formas atípicas de trabalho (trabalho por hora, por tarefa, temporário etc.), além dos processos de terceirização.

Segundo Dijkgraaf e Van der Zee (2009), as buscas por redução de custos e por flexibilidade têm levado os operadores postais a terceirizarem parte de suas atividades, sobretudo pela possibilidade de redução da massa salarial. Segundo os autores, a terceirização no serviço postal europeu tem se tornado importante nas atividades de coleta de malotes, serviços de escritórios (contabilidade, recursos humanos, etc.), transporte e encomendas expressas. Nessa direção, a coleta de malotes por empresas terceirizadas destaca-se em países como França (La Poste), Espanha (Correos), Bélgica (La Poste), Dinamarca etc.

A terceirização dos serviços de escritório é também recorrente na Europa, o que difere dos processos de terceirização de atividades finais das companhias. A maioria dos países da região faz esse tipo de terceirização, segundo os autores. Já a terceirização do transporte da carga postal ainda era incipiente em 2007, apesar de praticada em alguns países, permitindo a redução de 4.000 empregos só na Alemanha. De maneira semelhante, os processos de triagem e de entrega de encomendas expressas têm sido terceirizados em países da União Europeia.

Verifica-se, assim, que a flexibilidade dos contratos de trabalho naquele continente tem levado à terceirização em todas as atividades do serviço postal, sendo uma das faces da precarização do trabalho no setor.

A ECT, por sua vez, passou a contratar empresas de terceirização de mão de obra para dispor desses profissionais em diversas atividades nos anos 2000, sejam atividades-meio ou atividades-fim. No relatório de 
gestão de 2009 a estatal apresentou dados acerca da contratação de empresas terceirizadas para os serviços de brigada de incêndio, manutenção e conservação de bens móveis e imóveis, serviços de copa e cozinha, para gestão de programas de menores aprendizes, apoio administrativo e técnico operacional. A empresa passou a manter numerosos contratos realizados por estado e de acordo com demandas das Diretorias Regionais. Assim, os empregados públicos da ECT vêm trabalhando, cotidianamente, com diversos trabalhadores terceirizados.

Tem sido rotineiro nos ambientes operacionais, como os centros de distribuição e centros de tratamento de cargas, encontrar trabalhadores que foram contratados para prestar "apoio operacional", ou seja, trabalhar em atividades de suporte às tarefas.

A ECT tem se utilizado da terceirização nos cargos contemplados no PCCS - em suas atividades finalísticas, portanto, extrapolando o que é legalmente permitido. ${ }^{34}$ Por isso, instaurou-se um embate entre a empresa e os sindicatos acerca da definição das atividades que são finalísticas na estatal e, portanto, passíveis ou não de terceirização.

A Lei no. 6.538 de 1978, que regulamentou o setor postal, definiu como objetivos da ECT "a) planejar, implantar e explorar o serviço postal e o serviço de telegrama e b) explorar atividades correlatas", aspectos que foram mantidos com o aprofundamento da corporatização e a adoção de um novo estatuto para os Correios no governo Dilma Rousseff. O entendimento dos sindicatos tem sido que a terceirização de atividades de trabalho na captação, transporte, triagem e distribuição postal é ilegal e, portanto, precisa ser combatida.

A terceirização das atividades-fim da empresa teria aumentado, segundo os sindicalistas, a partir da segunda metade dos anos 2000, intensificando-se com a denominada "crise na ECT".

Os sindicalistas não dispõem de dados precisos sobre a quantidade de trabalhadores terceirizados que exercem ou exerceram nos últimos anos atividades finalísticas, mas têm conseguido comprovar a prática e levar a questão ao Poder Judiciário, onde a própria ECT tem admitido o expediente.

34 A Súmula 331 do Tribunal Superior do Trabalho define que somente as terceirizações em atividade-meio são legais, sendo quaisquer contratações em atividades finalísticas consideradas ilegais. 
Em 2008, o Sindicato dos Trabalhadores em Correios e Telégrafos e Similares do Piauí (SINTECT/PI) entrou com uma ação na Justiça do Trabalho contra a terceirização na ECT naquele estado. A ação trabalhista ajuizada em Teresina resultou na condenação da ECT e fundamentou o entendimento dos sindicatos, sendo a sentença proferida nos seguintes termos:

[...] Condenar a EMPRESA BRASILEIRA DE CORREIOS E TELÉGRAFOS - ECT a se abster de contratar trabalhadores em suas atividades fins através do instituto da terceirização, como motoristas, carteiros e operadores de triagem e transbordo, sem o devido concurso público; c. 2 - declarar como atividades-fins da ECT as atividades de transporte de carga (quer de viagens extraordinárias, quer de transporte rodoviário de carga postal através de linhas tronco regionais); c. 3 - declarar, com efeito ex nunc, a nulidade dos contratos em relação aos serviços da presente decisão, impedindo-se aditivos ou prorrogações dos referidos contratos, limitando-se os efeitos da presente decisão ao Estado do Piauí; tudo conforme fundamentação supra, que ora passa a integrar o presente dispositivo [...]. (BRASIL, 2012a)

Todavia, a decisão originou uma batalha jurídica. O sindicato exigia a imediata aplicação da sentença, enquanto a ECT tentava postergar a sua aplicação. Nesse sentido, a empresa entrou com recurso contra a decisão no Tribunal Regional do Trabalho da 22a Região, que reiterou a condenação:

'[...] Como bem ressaltado pelo membro do Ministério Público, além do transporte de cargas postais se tratar de atividade-fim, o cargo de motorista está contemplado no quadro de pessoal da reclamada, com atribuições definidas em seu plano de cargos e salários, revelando que a contratação de profissional desta espécie somente poderia se dar mediante concurso público.' Da mesma forma, estão previstos no plano de carreiras, cargos $e$ salários da recorrente os cargos de carteiro e operador de triagem e trasbordo (fls. 2.240 e 2.279 - vol. XXII). (BRASIL, 2012a, p. 2, grifo do autor)

Esses fatos evidenciam que a recorrente vem utilizando-se de terceirização de forma ilícita, contratando trabalhadores por empresa interposta para desempenho de funções permanentes e essenciais ao seu funcionamento e objeto, sem prévia aprovação em concurso público, contrariando as determinações legais pertinentes à espécie, inclusive o disposto no art. 37, II, da Constituição Federal. Na verdade, com razão o Ministério Público 
ao afirmar que estes trabalhadores temporários estão exercendo emprego público sem prévia submissão ao concurso público. (BRASIL, 2012a, p. 2, grifo do autor)

A questão foi parar no Tribunal Superior do Trabalho (TST), com o SINTECT/PI demandando o cumprimento da decisão e a ECT alegando que a sentença causaria "grave lesão à ordem e à economia públicas".

$O$ recurso da ECT no TST pleiteava também a suspensão do mandado de segurança obtido pelo SINTECT/PI para execução da sentença. Em 17 de maio de 2012, o ministro João Oreste Dalazen proferiu sua decisão, suspendendo o mandado de segurança favorável ao sindicato. $\mathrm{O}$ ministro considerou que $o$

[...] conceito de terceirização lícita padece de segurança jurídica”, além de alegar serem "imensas as dificuldades técnicas e operacionais para substituir o transporte de cargas realizado, hoje, por pessoas jurídicas, pelo serviço de empregados públicos concursados, em veículos que deverão ser adquiridos para essa finalidade. (BRASILa, 2012, grifo do autor)

A decisão do ministro, portanto, considera os argumentos da ECT e põe na berlinda a definição de legalidade pacificada na jurisprudência e na Súmula 331 do próprio Tribunal, instrumentos legais que normatizam a terceirização. Com isso, a ECT pode continuar a utilizar, no estado do Piauí, mão de obra terceirizada nas atividades de transporte até o julgamento final da questão no TST.

Contudo, a ação trabalhista movida pelo SINTECT/PI teve o seu alcance restrito àquele estado. Em razão disso, a FENTECT moveu ação civil pública contra a ECT na $13^{\circ}$ Vara do Trabalho do Tribunal Regional do Trabalho da $10^{\circ}$ Região (Brasília e Tocantins). Na ação, foi solicitada a imediata suspensão das contratações de terceirizados para as atividades operacionais, incluindo as atividades de transporte de objetos postais. As provas apresentadas basearam-se em editais de contratação de terceirizados, aditivos contratuais - eliminando o caráter temporário da contratação -, ações movidas pelo Ministério Público e decisões dos Tribunais Regionais. Diante disso, o juiz do trabalho proferiu sua sentença em caráter liminar favorável à FENTECT e concedeu a antecipação de tutela à entidade, em 23 de julho de 2012, nos seguintes termos: 
[...] Determina-se que a requerida [ECT] se abstenha de abrir qualquer processo licitatório, em todo o território nacional, até a apreciação do mérito desta demanda, que tenha como objeto a contratação de empresa fornecedora de mão de obra destinada ao exercício das seguintes atribuições, relacionadas à atividade-fim da estatal: a) Agente de Correios - Atividades Carteiro, Operador de Triagem e Transbordo, Atendente Comercial e Suporte; b) Técnico de Correios - Atividades Operacional, Atendimento e Vendas e Suporte; c) Especialista de Correios - Atividades Operacional, Comercial e Suporte. (BRASIL, 2012b)

Além disso, o juiz estabeleceu multa de $\mathrm{R} \$ 500.000,00$ por edital de licitação, caso a estatal descumpra a decisão. O processo judicial, todavia, ainda não está definido. Concomitantemente, o TST pode proferir sua sentença - na ação movida pelo SINTECT/PI - antes que a ação civil pública chegue àquela instância.

A ECT, diante disso, afirmou que "tomará as medidas cabíveis quando notificada", mas que as terceirizações não são ilegais e continuarão a ser utilizadas quando houver necessidade, como em períodos de contingência.

A terceirização nos Correios - seja de forma direta ou por meio da rede franqueada de agências - é coerente com o processo de externalização de atividades que se acentuou nas empresas brasileiras a partir da década de 1990, em busca de flexibilidade e redução de custos. Nesse sentido, ao tornarem a empresa "enxuta", alargam-se os processos de subcontratação, que visam focalizar e externalizar parte da produção, como argumenta Araújo (2004). Esse processo, diverso em suas modalidades, apresenta, de forma predominante, uma tendência à precarização do trabalho. (LEITE, 2009)

De acordo com Leite (2009), a terceirização e a precarização do trabalho aparecem como tendências que se aprofundam nos anos 1990 e continuam atuando nos dias atuais e aparecem sob formas variadas, como a subcontratação, a contratação de pessoas jurídicas para a realização de atividades antes exercidas por trabalhadores assalariados e a utilização de trabalho cooperado, dentre outras modalidades.

Apesar de a terceirização das atividades fins na ECT ocorrer a partir de meados dos anos 2000, o processo de precarização dessa mão de obra é evidente porque se trata de um mecanismo não só para atendimento de aumentos excepcionais do volume de objetos postais, mas também por 
ser um mecanismo de flexibilização do contingente de funcionários e de redução de custos.

Os trabalhadores terceirizados são contratados para atuar com vínculo temporário - três meses - como forma da estatal desvencilhar-se de obrigações trabalhistas. No jargão interno, os terceirizados são os MOTs, isto é, a mão de obra temporária. Os profissionais terceirizados não recebem os mesmos salários que os funcionários da ECT e não são contemplados pelos benefícios garantidos aos ecetistas nos acordos coletivos - assistência médica, previdência privada etc. -, o que já reduz significativamente os custos da folha de pagamentos da empresa pública.

No entanto, os problemas trabalhistas envolvendo as empresas terceirizadas contratadas pela ECT têm aumentado. Nesse sentido, há dois casos recentes que exemplificam os argumentos aqui apresentados. $\mathrm{O}$ primeiro refere-se à empresa NEO RH, que contratou entre 300 e 400 trabalhadores para a prestação de serviços como operadores de triagem e transbordo e carteiros no Paraná. Segundo os trabalhadores dessa empresa, é frequente o atraso do pagamento dos salários. Foi preciso uma intervenção do Ministério Público do Trabalho, por meio de um Termo de Ajustamento de Conduta, para que a empresa subcontratada e a ECT se comprometessem a resolver a situação. A ECT, na ocasião, responsabilizou a empresa terceirizada pelo problema. (SANTOS, 2012)

O segundo caso, bastante semelhante, refere-se à região de Campinas, em São Paulo, onde a empresa Worktime, fornecedora de mão de obra, também deixou de pagar os salários e benefícios em dia dos trabalhadores terceirizados. (SILVA, 2011) Diante desses casos, verifica-se que a força de trabalho terceirizada na ECT é, também, vitimada por um processo acentuado de precarização, reiterando as características desse mecaniso de subcontratação.

Apesar de não haver a publicação do número de trabalhadores terceirizados que exercem ou exerceram nos últimos anos atividades finalísticas na ECT, averígua-se que esse tem sido um instrumento de flexibilização dos contratos de trabalho. No entanto, a indefinição e o imbróglio jurídico envolvendo as atividades consideradas finalísticas não estão pacificados, como mostrou o voto do ministro do TST. Assim, os sindicalistas 
obtiveram uma vitória parcial que pode ser alterada até o julgamento final da matéria.

A despeito disso, o que se constata é a tentativa, por parte dos administradores da ECT, já no governo Lula, de flexibilizar os contratos de trabalho por meio do instrumento da terceirização. Na União Europeia, os processos de reestruturação postal levaram à demissão de inúmeros trabalhadores reduzindo drasticamente o número de empregados em tempo integral no setor e aumentando o número de subcontratações ou trabalhadores com vínculo parcial e/ou precário -, em um processo que também tinha como um de seus objetivos flexibilizar os contratos de trabalho.

\section{POLÍTICA SALARIAL COMO ESTRATÉGIA DE PERSUASÃO}

As transformações postais no cenário internacional têm impactado também as políticas de remuneração, sendo a redução salarial a estratégia privilegiada dos empresários do setor na eliminação dos custos da força de trabalho. Como os sistemas postais fazem uso intensivo de força de trabalho, a remuneração é alvo das estratégias que buscam diminuir custos por meio da flexibilização do trabalho ou sua redução.

Em todo o mundo, segundo a UNI Global Union (2009), as reduções salariais no setor postal têm acompanhado os processos de precarização dos postos de trabalho. É o caso da Holanda, cujo modelo de trabalho baseia-se em entregadores autônomos sem vínculo trabalhista e que recebem por objetos postais distribuídos. São trabalhadores que não têm direito a folgas remuneradas, seguro-saúde, seguro-desemprego etc. São trabalhadores precários e atípicos, com péssimas condições de trabalho. As empresas pagam por peça e para diminuir os custos impõem o limite de dois dias de trabalho por semana para cada trabalhador. Naquele país, um carteiro que trabalha para a TNT ganha por hora em torno de 15 euros. Somando os encargos (férias, seguro-saúde e desemprego etc.), sobe para 23 euros por hora. Já um distribuidor que trabalha para a Select Mail - que ganha por objeto postal distribuído - recebe em torno de 7,60 euros por hora. Com os contratos de trabalho para jornadas parciais ou contratos atípicos, as empresas não são obrigadas a pagar nem mesmo a 
seguridade social; para que isso aconteça, são estabelecidos mecanismos para que os funcionários não ultrapassem 16 horas de trabalho por semana, o que permite às empresas não pagarem nem $40 \%$ do salário mínimo local. (ABVAKABO..., 2011)

Diante dessa tendência de remuneração no setor postal internacional, qual tem sido a política de remuneração na ECT?

A estatal brasileira afirma que na reformulação de seu plano de carreiras e salários de 2008 o sistema remuneratório adotado "baseia- se na chamada abordagem total da remuneração". Isso significa que a empresa assume a complementaridade dos diversos componentes da remuneração, sejam benefícios legais, opcionais ou resultantes de negociações coletivas.

Trata-se, assim, de uma política salarial caracterizada por um welfare privado, cuja característica principal é assumir que os benefícios concedidos aos funcionários da empresa integram um salário indireto. A consequência inicial desse sistema de remuneração é a associação, pelos trabalhadores, do seu bem-estar social à empresa (MELLO; SILVA, 1999), sendo, portanto, muito importante no processo de construção do consentimento entre os trabalhadores. (BURAWOY, 1979)

O sistema de remuneração dos trabalhadores da ECT é constituído por um salário-base de ingresso no cargo - o piso da tabela salarial. A tabela salarial apresenta um conjunto de salários destinados aos funcionários e são agrupados conforme índices crescentes de remuneração: são as referências salariais. A partir disso, tem-se a amplitude salarial. Assim, por exemplo, os funcionários de nível médio possuem uma tabela salarial com noventa referências salariais (níveis). Cada referência salarial corresponde à progressão salarial em decorrência da antiguidade do funcionário ou mérito - sendo que ambos não são concedidos no mesmo ano. São, nas palavras da empresa, os "estágios de desenvolvimento" de cada funcionário e que permitem reajustes anuais.

Os trabalhadores da carreira de nível médio possuem as seguintes referências salariais:* 
FIGURA 10 - FAIXA SALARIAL DE NÍVEL MÉDIO

\begin{tabular}{|c|c|c|c|}
\hline \multicolumn{4}{|c|}{ CARREIRA DE NÍVEL MÉDIO } \\
\hline \multirow{3}{*}{ CARGOS } & \multicolumn{3}{|c|}{ ESTÁGIOS DE DESENVOLVIMENTO } \\
\hline & \multicolumn{3}{|c|}{ FAIXAS SALARIAIS } \\
\hline & $J R$ & PL & SR \\
\hline Técnico de Correios & NM31 a NM88 & NM45 a NM 88 & NM 59 a NM88 \\
\hline \multirow{2}{*}{ Especialista de Correios } & \multicolumn{3}{|c|}{ FAIXA SALARIAL } \\
\hline & \multicolumn{3}{|c|}{ NM75 a NM9O } \\
\hline
\end{tabular}

Fonte: PCCS 2008

*As referências salariais são identificadas pelo nível do cargo.

Assim, NM corresponde à referência salarial de nível médio.

A figura 22 mostra a amplitude salarial dos trabalhadores de nível médio. Verifica-se que os Agentes de Correios são enquadrados em uma tabela salarial com sessenta referências. Em 2011/2012, o salário inicial desses trabalhadores oscilava entre NM01, equivalente a R \$942,75, e NM60, correspondendo a $\mathrm{R} \$ 3.133,80$ (última referência salarial).

Um ocupante do cargo de Técnico de Correios com NM31 em início de carreira recebia $\mathrm{R} \$ 1.677,13$, enquanto o salário básico de um especialista começava em NM75, isto é, R\$4.401,43, podendo chegar até NM90, ou seja, R\$ 6.232,17. Já os funcionários de nível superior (NS) possuíam uma tabela salarial específica, que se estendia de NS03 a NS60, com faixas intercaladas conforme o estágio de desenvolvimento na carreira (júnior, pleno, sênior e máster). Já o salário inicial dos ocupantes de cargos de nível superior, em 2011, iniciava-se em R $\$ 3.211,58$.

Além do salário-base correspondente ao tempo de serviço e à "progressão funcional", os funcionários da ECT contam com benefícios que integram a política de remuneração. Dentre os benefícios se destacam como parte da "remuneração abrangente e total", nos termos da ECT, os negociados em acordos coletivos e que possuem importância econômica para os trabalhadores, destacando-se os seguintes:

QUADRO 6 - BENEFÍCIOS PREVISTOS NO ACORDO COLETIVO 2009/2011

\begin{tabular}{|l|l|l|}
\hline Benefícios & Características & Valores \\
\hline Vale-Cesta & $\begin{array}{l}\text { Difere-se do vale-alimentação por ser } \\
\text { destinado ao consumo, unicamente, } \\
\text { de produtos alimentícios. }\end{array}$ & No valor de R\$ 130,00. \\
\hline
\end{tabular}




\begin{tabular}{|l|l|l|}
\hline $\begin{array}{l}\text { Vale-Alimentação } \\
\text { ou Vale-Refeição }\end{array}$ & $\begin{array}{l}\text { Atualmente, a empresa terceiriza o } \\
\text { serviço e concede aos funcionários um } \\
\text { cartão da empresa contratada para } \\
\text { administrar o benefício. São creditados } \\
23 \text { vales para os funcionários por } \\
\text { mês. Funciona em sistema de } \\
\text { compartilhamento de 5\% a 15\%. }\end{array}$ & $\begin{array}{l}\text { Cada vale-alimentação } \\
\text { apresenta valor facial de } \\
\text { R\$23,00. São depositados, } \\
\text { mensalmente, R\$ 529,00. }\end{array}$ \\
\hline $\begin{array}{l}\text { Plano de saúde corporativo } \\
\text { Assistência médico- } \\
\text { hospitalar e odontológica) }\end{array}$ & $\begin{array}{l}\text { Atende aos funcionários na } \\
\text { ativa, aposentados e respectivos } \\
\text { dependentes. Possui rede credenciada } \\
\text { e conveniada bastante abrangente. }\end{array}$ & $\begin{array}{l}\text { Funciona em sistema de } \\
\text { compartilhamento de 10\% a } \\
\text { salarial. "Paga mais quem ganha } \\
\text { mais". Acidentes de trabalho } \\
\text { não são compartilhados. }\end{array}$ \\
\hline $\begin{array}{l}\text { Auxílio para filhos, enteados } \\
\text { e tutelados portadores de } \\
\text { necessidades especiais. }\end{array}$ & $\begin{array}{l}\text { Reembolso aos funcionários para } \\
\text { despesas com recursos especializados } \\
\text { no atendimento dos dependentes } \\
\text { com necessidades especiais. }\end{array}$ & $\begin{array}{l}\text { R\$ 571,74 por dependente. Se } \\
\text { for preciso, o serviço médico } \\
\text { e social da empresa pode } \\
\text { autorizar reembolsos maiores. }\end{array}$ \\
\hline Reembolso creche e babá. & $\begin{array}{l}\text { Concedido às empregadas com } \\
\text { filhos, crianças sob tutela ou filhos } \\
\text { adotivos até o sétimo aniversário. }\end{array}$ & $\begin{array}{l}\text { R\$ 360,20. Até o primeiro } \\
\text { aniversário da criança, a empresa } \\
\text { assume integralmente o valor; } \\
\text { nos demais, a empregada } \\
\text { contribui com 5\%. }\end{array}$ \\
\hline
\end{tabular}

Fonte: Acordo coletivo 2009/2011.

Apesar de a empresa argumentar que sua política remuneratória é "abrangente e total", os benefícios garantidos aos funcionários são bem mais antigos que o PCCS de 2008. Em 1988, no primeiro acordo coletivo, os funcionários já usufruíam de benefícios como vale-alimentação/ refeição, assistência médico-hospitalar e odontológica e auxílio-creche para as funcionárias, condições que foram mantidas no acordo seguinte, em 1989. Em 1992, os trabalhadores conquistaram ainda o auxílio aos filhos com necessidades especiais e acesso à cesta básica "contendo produtos de alimentação e higiene pessoal". Ainda em 1992, os funcionários também passaram a ter o direito à licença adoção. São esses benefícios que constituem, assim, a estrutura da cesta de remuneração da ECT há mais de vinte anos. Desde então, o que os sindicatos e a FENTECT têm pleiteado e conquistado são melhorias, como a ampliação da rede credenciada do plano de saúde e a redução do compartilhamento com os funcionários das despesas com os benefícios (caso do vale-alimentação e refeição, plano de saúde, e também dos auxílios concedidos às empregadas - auxílio-creche e auxílio aos filhos com necessidades especiais). 
Além desses benefícios, há outros que a ECT é obrigada a fornecer aos funcionários em cumprimento à legislação trabalhista. Mesmo assim, em alguns casos, os sindicatos têm conseguido em negociações algumas vantagens. É o caso da jornada semanal de trabalho, que foi reduzida para 40 horas e com um acréscimo para os funcionários que trabalham aos sábados. Com isso, os funcionários que são da escala de sábado recebem 15\% de acréscimo aos salários e, caso algum funcionário que não seja da escala seja convocado, tem direito a receber um quarto $15 \%$ por sábado trabalhado, mais um vale-alimentação. Em casos de convocações para trabalhar em dia de repouso semanal remunerado e em feriados, as entidades sindicais conquistaram o direito a $200 \%$ de acréscimo sobre a jornada em dias úteis ou a duas folgas.

Os benefícios são importantes na política salarial da ECT porque complementam o salário básico dos funcionários, fazendo com que o aumento da remuneração mensal proporcione à empresa a disponibilidade de funcionários. É o caso, assim, das horas extraordinárias, pagas com acréscimo de $70 \%$ sobre a hora normal ( $20 \%$ a mais que o mínimo permitido), o que objetiva o aumento da dedicação e permanência do funcionário na empresa para aumentar a sua remuneração.

Alguns benefícios, no entanto, se destacam como mais importantes no processo de construção do convencimento necessário para garantir a permanência dos funcionários no emprego: o plano de saúde e os vales-alimentação, refeição e cesta. Isso porque nem todos os benefícios apresentados no quadro 7 são concedidos aos funcionários, como é o caso do auxílio aos filhos com necessidades especiais e o auxílio-creche.

Os benefícios que integram a política de remuneração, juntamente com a relativa estabilidade funcional, embasam o convencimento necessário à manutenção da força de trabalho na ECT, além de garantir a própria reprodução dessa força de trabalho. Ao adotar essa estratégia salarial, a empresa reconhece ser essa a sua peculiaridade, como consta no relatório social de 2005 (p. 14, grifo nosso):

[...] os Correios têm uma preocupação constante com a qualidade de vida de seus empregados, oferecendo a eles e a seus familiares um respeitável leque de benefícios. Esse, aliás, é o grande diferencial da política de recursos humanos dos Correios. 
No mesmo sentido, no relatório de gestão de 2008 a empresa reitera este posicionamento: "Os benefícios oferecidos pela Empresa têm se mostrado importante diferencial para a atratividade e satisfação dos empregados".

A relação entre salário-base e remuneração revela, portanto, algo peculiar na política de produção da ECT: a importância dos benefícios na composição da remuneração e seu papel na construção do convencimento dos funcionários.

Para melhor compreender esse aspecto, é preciso observar a importância dos benefícios em relação ao salário-base. Antes disso, no entanto, vejamos a distribuição da remuneração dos funcionários em maio de 2010 na tabela a seguir:

TABELA 2 - DISTRIBUIÇÃO DOS EMPREGADOS POR NÍVEL DE REMUNERAÇÃO*:

\begin{tabular}{|c|c|c|c|c|}
\hline Faixa Salarial & Mulheres & Homens & Total & \\
\hline 1 a $2 \mathrm{SM}^{\star \star *}$ & 2.122 & 3.717 & $5.839(5,4 \%)$ & Até $\mathrm{R} \$ 1.020$ \\
\hline $3 a 45 M$ & 14.662 & 46.588 & $61.250(56,7 \%)$ & Entre $R \$ 1.530$ e $R \$ 2.040$ \\
\hline 5 a 9 SM & 6.782 & 28.121 & $34.903(32,3 \%)$ & Entre $R \$ 2.550$ e $R \$ 4.590$ \\
\hline 10 a 14 SM & 1.164 & 2.136 & $3.300(3,05 \%)$ & Entre $R \$ 5.100$ e $R \$ 7.140$ \\
\hline 15 a 19 SM & 409 & 919 & $1.328(1,2 \%)$ & Entre $R \$ 7.650$ e $R \$ 9.690$ \\
\hline 20 a 24 SM & 187 & 598 & $785(0,726 \%)$ & Entre $R \$ 10.200$ e $R \$ 12.240$ \\
\hline 25 ou mais SM & 114 & 473 & $587(0,543 \%)$ & Acima de $R \$ 12.750$ \\
\hline Total & 25.440 & 82.552 & $107.992(100 \%)$ & \\
\hline
\end{tabular}

Fonte: adaptado a partir de dados internos.

*Por remuneração deve-se entender o vencimento (salário) acrescido das vantagens pecuniárias.

** SM: salário mínimo. Valor do salário mínimo em 31/12/2010: R\$ 510,00.

De acordo com os dados apresentados na tabela 2, verifica-se que a remuneração concentra-se na faixa de três a quatro salários mínimos, com 56,7\% dos trabalhadores nessa faixa salarial. Em seguida, os funcionários que recebem de cinco a nove salários mínimos de remuneração integram o segundo maior grupo, com 32,3\%. Em maio de 2010, esses valores correspondiam às remunerações entre $\mathrm{R} \$ 1.530$ e $\mathrm{R} \$ 2.040$, no primeiro grupo, e ao intervalo entre $R$ \$ 2.550 e $R \$ 4.590$ no segundo. Seguindo esses dados apresentados 
pelos Correios à Secretaria de Política para as Mulheres, a remuneração dos funcionários estaria acima da média de mercado para o perfil dos trabalhadores e trabalhadoras, que ocupam majoritariamente cargos de nível médio.

No entanto, ao analisar a relação salário e benefícios fixos, a situação se mostra mais realista, já que os encargos trabalhistas e benefícios previdenciários só incidem sobre o salário-base. A tabela de remuneração, inclusive, não aponta os mecanismos internos de concessão de gratificações, que aumentam consideravelmente os salários de referência e que não são concedidas a todos os empregados, e que, por isso, podem não representar a realidade ao se considerar as remunerações de forma homogênea.

Assim, vamos considerar apenas a relação entre salário e benefícios econômicos concedidos a todos os funcionários em três cargos para melhor apreensão da política salarial:

TABELA 3 - CARGOS, REFERÊNCIAS SALARIAIS E BENEFÍCIOS*

\begin{tabular}{|c|c|c|c|}
\hline Cargos & Faixa salarial & $\begin{array}{l}\text { Referências salariais mais } \\
\text { representativas entre o efetivo }\end{array}$ & $\begin{array}{l}\text { Benefício Fixo } \\
\text { (Vale-alimentação } \\
\text { + vale-refeição) }\end{array}$ \\
\hline $\begin{array}{l}\text { Nível médio } \\
\text { Agente de } \\
\text { Correios }\end{array}$ & $\begin{array}{l}\text { NM01 R\$ 807,29 } \\
\text { NM60 R\$2.857,40 }\end{array}$ & $\begin{array}{l}\text { NM01 (R\$ 807,29) com 12,01\%; NM15 } \\
\text { (R\$1.066,57) com 9,66\%; NM16 (R\$ } \\
\text { 1.088,98) com 10,91\%. Nas demais, } \\
\text { o pico não representa nem 4\%. }\end{array}$ & $R \$ 659$ \\
\hline $\begin{array}{l}\text { Nível médio } \\
\text { Técnico de } \\
\text { Correios }\end{array}$ & $\begin{array}{l}\text { NM31 R\$1.494,46 } \\
\text { NM88 R\$5.490,68 }\end{array}$ & $\begin{array}{l}\text { A NM34 (R\$1.545,91) é a maior do grupo, } \\
\text { representando 3,43\%. Acima da NM } 51 \\
\text { (R\$2.327,15), o efetivo não soma nem } 1 \% \text {. }\end{array}$ & $R \$ 659$ \\
\hline $\begin{array}{l}\text { Nivel superior } \\
\text { Analista de } \\
\text { Correios }\end{array}$ & $\begin{array}{l}\text { NS01 R\$3.061,88 } \\
\text { NS60 R\$12.812,34 }\end{array}$ & $\begin{array}{l}\text { A NM } 03 \text { (R\$ 3.211,58) apresenta maior } \\
\text { contingente de trabalhadores, isto é, } \\
810 \text { - ou } 0,75 \% \text { do efetivo. As demais } \\
\text { não atingem nem esse contingente. }\end{array}$ & $R \$ 659$ \\
\hline
\end{tabular}

Fonte: elaboração própria a partir de dados internos.

*Maio de 2010.

Ao se observar a relação entre salário-base e benefícios fixos - que independem de critérios específicos para concessão - para os cargos de nível médio, verifica-se que na referência salarial mais elevada para os Agentes de Correios (NM60 - R\$ 2.857,40), o benefício equivale a mais de $23 \%$ do salário. Se considerarmos a NM01, a mais baixa, o benefício corresponde a cerca de $81 \%$ do salário-base. Como os trabalhadores de nível médio são maioria na empresa, a massa salarial desse grupo é a mais representativa entre os trabalhadores da estatal. 
Para os cargos de nível técnico, verifica-se que os benefícios também são importantes para o pequeno grupo de funcionários desses cargos, correspondendo a mais de $42 \%$ da referência salarial dos trabalhadores que recebiam a NM34. Considerando os cargos de nível superior enquadrados na referência salarial com mais trabalhadores, a NM 03 ( $\mathrm{R} \$ 3.211,58$ ), o benefício representa $20,5 \%$ do salário de referência.

Os dados, portanto, evidenciam como benefícios que se destinam à alimentação e refeição - o vale-alimentação, refeição e o vale-cesta - são importantes na composição da remuneração dos trabalhadores, sobretudo dos cargos de nível médio, cuja remuneração quase dobra. Se comparados aos salários de outras empresas públicas, os salários de nível médio dos ecetistas são baixos. Porém, quando acrescidos dos benefícios, quase dobram e, juntamente com demais mecanismos de remuneração, passam a compor uma massa salarial que atua no convencimento dos trabalhadores para permanecerem na empresa.

Há ainda um último aspecto, mas não menos importante, que deve ser considerado na política de remuneração dos Correios: as gratificações recebidas pelo exercício de funções ou atividades especiais. As funções gratificadas podem ser gerenciais, técnicas e de atividade especial. Na tabela 4 , verifica-se o percentual de funcionários que fazem jus ao recebimento de gratificações pelo exercício de funções:

TABELA 4 - PERFIL DAS GRATIFICAÇÕES POR FUNÇÃO*

\begin{tabular}{|l|l|l|}
\hline Função & Efetivo com Função & Percentual do Efetivo \\
\hline Apoio Operacional/ Técnico & 2.983 & $2,7 \%$ \\
\hline Atividade Especial & 28.013 & $25,8 \%$ \\
\hline Confiança & 14.307 & $13,18 \%$ \\
\hline Gerencial & 1.929 & $1,77 \%$ \\
\hline Gratificada & 1.531 & $1.41 \%$ \\
\hline Técnica & 1.845 & $1,7 \%$ \\
\hline Total & 50.608 & 50.608 (46,6\% do efetivo total) \\
\hline Total do Efetivo & $\begin{array}{l}\text { Total Sem Função } \\
57.908\end{array}$ & $\begin{array}{l}108.516 \\
(100 \%)\end{array}$ \\
\hline
\end{tabular}

Fonte: elaboração a partir de dados internos.

*Os valores são referentes a agosto de 2010. Houve a atualização do Manual de Pessoal, e no final de 2011 as funções Apoio Operacional e Técnico e de Confiança foram extintas, sendo incorporadas às de tipo gerencial, técnicas e às atividades especiais. 
O primeiro aspecto que deve ser destacado a partir dos dados é a alta representatividade de trabalhadores com gratificações na empresa. De um total de 108.516 trabalhadores e trabalhadoras à época, quase $47 \%$ do efetivo possuem algum tipo de função gratificada. Isto poderia conduzir à percepção equivocada de que há muitos trabalhadores exercendo cargos típicos de chefia na empresa. Aliás, esta foi a conclusão do jornal $O$ Globo em reportagem intitulada "Correios têm um chefe para cada dois servidores [...]”. (CORREIOS..., 2011) Na matéria, os jornalistas afirmam que "Dados obtidos com exclusividade pelo GLOBO mostram, por exemplo, que há um funcionário comissionado (em cargo de chefia) para cada dois servidores" e, como o título da reportagem sugere, que "[...] os Correios têm hoje quase um 'chefe' para cada dois trabalhadores [...]”. Os jornalistas calcularam e relacionaram diretamente funções à "chefia" e isso, certamente, permite chegar à conclusão da reportagem que, no entanto, é equivocada. É equivocada porque não considera as especificidades das funções e o que significam na estrutura funcional da estatal.

Para entender a natureza das funções existentes na ECT é preciso considerar que há duas categorias de funções: as que consistem em ascensão profissional e as exercidas pelos trabalhadores.

No primeiro grupo, encontram-se as funções técnicas e gerenciais. São funções gratificadas exercidas, por exemplo, por diretores regionais, coordenadores de área, gerentes corporativos e regionais, gerentes de unidades operacionais, supervisores operacionais, instrutores etc. São funções que se destacam pela presença de subordinados. É o caso, por exemplo, de Assessores de Relações Sindicais das Diretorias Regionais, que recebem a gratificação de função (entre $\mathrm{R}$ \$1.110,30 e R \$ 1.558,23) acrescida de uma remuneração (entre $R \$ 6.494,67$ e R $\$ 10.700$, 87). Já um Supervisor de Operações nas Diretorias Regionais é remunerado com valores menores, entre $\mathrm{R} \$ 413,47$ e $\mathrm{R} \$ 527,71$.

O segundo grupo de funções, no entanto, apesar de gratificadas, não implica em exercício de chefia. São as Atividades Especiais, atribuídas aos empregados em razão da utilização de equipamentos específicos ou condições de trabalho especiais, que são vinculadas às tarefas dos cargos. Os trabalhadores que executam atividades especiais recebem apenas um valor 
de gratificação estipulado nas negociações coletivas. As ditas "atividades especiais" são exercidas por funcionários motorizados (veículos ou motos), operadores de empilhadeira, operadores de equipamentos de segurança postal, operadores de teleatendimento, quebra de caixa em agências, etc.

Nessas "Atividades Especiais", os funcionários recebem adicionais salariais sem que seja alterada a sua situação profissional. Os valores dos adicionais eram, no caso de quebra de caixa para atendentes comerciais, de R \$ 140,58 ou R \$ 187, 44 - em caso de agências com Banco Postal. Já um Agente de Correios motorizado recebia R $\$ 220,77$.

Os carteiros, operadores de triagem e transbordo e atendentes comerciais, por sua vez, recebem um adicional de no máximo 30\% do salário-base pelo exercício das "atividades especiais" dos cargos. ${ }^{35}$

Assim, verifica-se que os adicionais são baixos e representam um acréscimo ao salário-base. Não se trata, assim, de ascensão funcional, como argumentado pelos jornalistas. Dessa maneira, o trabalhador e a trabalhadora recebem apenas um adicional ao salário-básico pelo exercício de uma "atividade especial" que é enquadrada como função gratificada na denominação da empresa.

O que os dados evidenciam é o fato de a política de remuneração da ECT conceder maiores benefícios salariais aos trabalhadores que ocupam cargos de nível superior e com funções de confiança e gerenciais - que recebem maiores salários e gratificações.

Em razão disso, inclusive, a FENTECT denuncia a disparidade salarial existente na empresa entre cargos de nível médio e superior, justificando, assim, as reivindicações para maiores reajustes para os ocupantes de cargos de nível médio. A Associação dos Profissionais de Níveis Superior, Técnico e Médio da ECT (ADCAP) alega que a FENTECT não a representa nas negociações com a empresa, porque não garante a representação dos interesses dos funcionários de nível superior.

35 O carteiro recebe o Adicional de Atividade de Distribuição e/ou Coleta; o OTT possui o Adicional de Atividade de Tratamento; o atendente comercial, o Adicional de Atendimento em Guichê em Agências de Correios. 
Isso reforça a percepção dos funcionários, como mostrado por Junquilho e Silva (2004) em estudo sobre aspectos culturais existentes entre os funcionários dos Correios, da existência de uma cisão na empresa entre a área operacional e administrativa, além da separação entre gestores e trabalhadores na área operacional.

A política salarial e de remuneração, assim, é o embasamento econômico de uma divisão entre áreas na empresa, que se sustenta pelas estratégias de gestão que reforçam a cisão entre concepção e execução no ambiente de trabalho e hierarquizam funcionários com base na área de atuação - administrativo ou operacional - e remuneração.

Um dos instrumentos mais utilizados pela ECT para apreender a percepção dos trabalhadores sobre a atuação da empresa é a pesquisa de clima organizacional. Em uma delas, a estatal constatou que em todas as Diretorias Regionais o índice de satisfação dos funcionários em relação à remuneração ficou em torno de $60 \%$, raramente ultrapassando tal índice. (ROSA, 2009) $)^{36}$

Ao mesmo tempo, o quesito "benefícios" obteve a aprovação média de mais de $85 \%$ dos funcionários nas pesquisas realizadas desde 2005. Se comparado ao fator "condições de trabalho" - que não ultrapassou 70\% de "favorabilidade" (sic) até 2008 -, verifica-se a relevância dos benefícios no grau de satisfação dos funcionários. Com isso, a estratégia de remuneração nos Correios tem s ido um importante elemento no processo de construção do convencimento dos trabalhadores.

\section{A participação nos lucros e resultados como estratégia de remuneração variável e flexível}

Os programas de remuneração variável, como a participação nos lucros e resultados (PLR), são importantes instrumentos para flexibilização da remuneração. (CARVALHO NETO, 2001)

A utilização da PLR como instrumento de remuneração variável tornou-se uma tendência a partir da década de 1970, na Suécia e, nos anos

36 Os dados se referem aos anos de 2005, 2006 e 2007. 
1980, na Itália, sendo que no início dos anos 1990, de acordo com Carvalho Neto (2001), já era prática bastante difundida e utilizada em países centrais da economia capitalista. Assim, quando houve a regulamentação da PLR no Brasil, em 1994, ela já era uma prática bastante difundida de flexibilização da remuneração.

Em seu aspecto legal, a PLR só foi regulamentada com a Medida Provisória (MP) nº. 794, de 29 de dezembro de 1994, posteriormente convertida na Lei no. 10.101, de 19 de dezembro de 2000. Assim, mesmo a PLR sendo a modalidade de remuneração variável mais utilizada no Brasil, sua regulamentação é recente.

Dentre os princípios ${ }^{37}$ que orientaram a regulamentação da PLR há o que sugere ser o programa um meio de integração entre capital e trabalho, além de uma ferramenta de incentivo à produtividade. Diante disto, averígua-se que a ideologia acionada durante a redação dos instrumentos legais e normativos corrobora os discursos empresariais que advogam a necessidade de incrementar os ganhos de produtividade e tentam cooptar os trabalhadores por meio de uma suposta convergência de interesse entre classes sociais.

O programa de participação nos lucros e resultados (PLR) dos Correios foi instituído em 2003 e, desde então, negociações têm sido realizadas com representantes dos funcionários para distribuição de parte dos lucros. Entretanto, desde 1997 a ECT planejava implantar a PLR como parte de sua política de gestão. No entanto, a existência de uma Gratificação de Qualidade e Produtividade (GQP) obstava a anuência do governo federal para implantação da PLR por haver uma suposta semelhança entre os programas. Em 2000, a GQP foi extinta e incorporada aos salários, o que permitiu a retomada das negociações para implantação da participação nos lucros. Desde então, a ECT passou a pleitear

37 Os programas de PLR, conforme estabelece a regulamentação, devem ter regras claras e objetivas, tendo como critérios e condições: a necessidade de negociação entre empresas e comissões de empregados, com a necessária representação sindical; vinculação a índices de produtividade, qualidade e lucratividade, programas de metas, resultados e prazos pactuados; a não constituição da PLR de base para qualquer encargo trabalhista ou previdenciário; e a liberdade dos empresários de não seguirem o princípio da habitualidade. 
autorização do Ministério do Planejamento, Orçamento e Gestão para implantação de seu programa de remuneração variável. A autorização foi concedida ao final de 2002, o que possibilitou à estatal implantá-la a partir do ano seguinte. (EMPREGADO..., 2002)

As motivações para implantação da PLR podem ser apreendidas a partir do discurso dos dirigentes da ECT e das matérias nos jornais corporativos à época:

A PLR estimula a produtividade e estreita a relação empregado-empresa. É um reconhecimento ao esforço dos trabalhadores. Diretor regional e coordenador do grupo de trabalho para implantação da PLR. (PARTICIPAÇÃO..., 2000)

O sistema de ganhos variáveis, em princípio, apresentaria vantagens como o reforço da cultura participativa e do trabalho em grupo, além de incentivar a busca por inovações e centros de lucro. 'A remuneração é uma troca entre empregado e empresa, benéfica para os dois lados', diz a chefe da Divisão de Planejamento de Cargos e Salários do Departamento de Administração de Recursos Humanos (Darec). 'Ao mesmo tempo em que estimula o empregado, o mecanismo incrementa a produtividade.' (VANTAGENS..., 2000)

[...] a PLR significa reconhecimento à contribuição dos empregados para o sucesso da empresa. Sua instituição possibilita estreitamento nas relações entre capital e trabalho e estimula a busca pelo aumento da qualidade e da produtividade. (EMPREGADO..., 2002)

A direção da ECT, consoante à ideologia que orientou a regulamentação da PLR, considera a remuneração variável um instrumento de "integração entre capital e trabalho [capaz de] promover a melhoria da condição social, incentivar a lucratividade e a qualidade dos produtos e serviços prestados.” (ECT, 2008, p. 1)

Segundo Krein (2009), a centralidade que a PLR adquiriu nas negociações coletivas a partir de 1995 e o relativo consenso que a envolve decorrem do fato de haver entre os trabalhadores certo entusiasmo em auferir um bônus extra anualmente, mesmo que o valor seja variável; nas grandes empresas, destaca o autor, o valor da PLR pode ser significativo para os trabalhadores. Por parte dos empregadores, a PLR possibilita vincular o 
valor a ser distribuído ao desempenho individual ou mesmo empresarial, além de permitir o estabelecimento de metas para os trabalhadores. Ao fazerem isso, os empresários acreditam em um possível aumento da competitividade e da lucratividade das empresas. (KREIN, 2009)

O discurso da ECT acerca da suposta convergência de interesses entre capital e trabalho alinha-se, portanto, à ideologia que permeou a redação dos instrumentos legais. Segundo a ECT (2008b, p. 01), o objetivo foi instituir a PLR como instrumento de gestão de pessoas, já que isto permitiria à estatal "[...] comprometer os empregados para com os resultados que a empresa objetiva atingir, principalmente os relacionados à produtividade, qualidade e lucratividade", além de "melhorar o clima organizacional, incentivar a postura empreendedora" dos funcionários e "despertar a cultura da lucratividade com qualidade e produtividade e a eliminação dos desperdícios." (ECT, 2008b, p. 01)

Ao estabelecer seu plano de remuneração variável, portanto, a ECT explicita que seu intento é vincular os critérios de distribuição da PLR com indicadores de desempenho. Assim, trata-se de mecanismo de gestão que busca ligar metas empresariais ao desempenho dos funcionários, como discutido por Carvalho Neto (2001) e Krein (2009). Além disso, os Correios evidenciam que um de seus propósitos é ideológico ao asseverar que objetiva "despertar a cultura da lucratividade" associada à "eliminação do desperdício", isto é, almeja um comprometimento dos funcionários e que eles "vistam a camisa" da empresa, como apontou Krein (2009).

Como parte das estratégias em instituir a PLR como instrumento de gestão, em 2003 foram estabelecidos três critérios para definição dos valores a distribuir: metas corporativas - correspondendo a 50\% da parcela -; metas das Diretorias Regionais - 30\% -; e metas pautadas pela avaliação individual (20\%). A avaliação dos funcionários foi estabelecida inicialmente a partir de critérios estipulados no Gerenciamento de Competências e Resultados, sendo preciso obter os conceitos A, B, C ou D para ter direito à distribuição. Além disso, foi definido que o pagamento seria proporcional aos dias trabalhados.

A partir desses critérios, em 2003 a ECT distribuiu R\$ 13.690 milhões, aumentando em 2004 o valor para $\mathrm{R} \$ 22.708$ milhões (0,67\% da folha de 
pagamento bruta). Em 2005, os valores distribuídos a título de PLR foram de R 47.071 milhões (1,18\% da folha). Já em 2006 e 2007 os valores foram, respectivamente, em torno de $\mathrm{R} \$ 62.019$ e $\mathrm{R} \$ 95.431$ milhões.

De acordo com o Relatório Empresarial da ECT de 2007,

O montante de R\$ 95 milhões refere-se à participação dos empregados no resultado positivo do exercício de 2007, que será pago no curso de 2008, conforme Acordo Coletivo de Trabalho, e o valor de R $\$ 431,1$ mil referem-se ao saldo remanescente da PLR de 2006, cujo pagamento não foi efetuado em virtude dos empregados envolvidos encontrarem-se afastados. [sic]

Em 2007, no entanto, a ECT apresentou uma novidade em seu programa de remuneração variável. A partir de então, os gestores ocupantes de cargos considerados estratégicos (diretoria da estatal) fariam jus à PLR sob a alegação de ser um dos objetivos do programa "premiar o esforço individual e coletivo". Com isso, dois grupos diferenciados seriam formados: o grupo de gestores estratégicos e o dos funcionários táticos e operacionais. Até então, somente os últimos recebiam a PLR. A partir disso, os lucros ou resultados passaram a ser divididos em dois segmentos.

Cabe relembrar que os funcionários da ECT são organizados conforme o cargo e a função que exercem, sendo divididos em grupos: estratégico (formado pela direção da empresa), tático (ocupam cargos de gerência intermediária), operacional e execução - carteiros, operadores de triagem e transbordo, motoristas, atendentes de agências etc. Essa divisão funcional passou a orientar o pagamento da PLR - sendo diferenciados, inclusive, o valor e os critérios de distribuição para cada grupo.

Dentre os novos critérios implementados a partir de 2007, 55\% da parcela seria linear e de acordo com as faltas injustificadas; $30 \%$ seriam referentes à parcela regional (metas da diretoria regional); e 15\% referentes ao desempenho individual de cada trabalhador e vinculados à sua avaliação no GCR. Além disso, a remuneração média de cada trabalhador passou a ser considerada. Assim, os critérios passaram a ser remuneração média, meses trabalhados, faltas injustificadas, GCR (avaliação A, B e C) e metas corporativas.

Em 2006, entre os funcionários dos níveis operacional e tático, o menor valor recebido foi de $\mathrm{R} \$ 526$, 51, enquanto em 2007 se esperava que 
pudesse ser $\mathrm{R} \$ 508,02$. Já o maior valor recebido foi de $\mathrm{R} \$ 1.624,90$ e a previsão para 2007 era de $\mathrm{R} \$ 4.259,76$. A média entre 2006 e 2007 seria pouco alterada, saindo de $\mathrm{R} \$ 612,00$ para $\mathrm{R} \$ 650,00$. Entretanto, a diferença entre a maior e a menor parcela saltaria de três vezes para mais de oito.

Com isso, a proposta do Departamento de Gestão das Relações Sindicais e do Trabalho (DEGET) da ECT era, deliberadamente, incluir os diretores da estatal no programa de remuneração variável a partir do aprofundamento das desigualdades nesta modalidade de remuneração já que também seria baseada na remuneração fixa de cada funcionário. Além disso, os novos critérios proporcionariam um maior distanciamento até mesmo entre os valores recebidos pelos funcionários dos grupos tático e operacional. Como o DEGET explicou, "A diferença nacional entre os maiores valores de PLR foi de apenas R \$ 300" em 2006, enquanto que com os novos critérios para 2007 a previsão seria que "A diferença entre os maiores valores de PLR [dos] empregados de nível tático e operacional seria de R \$ 3.500." (ECT, 2007b)

Por que esse comportamento deliberado dos gestores da ECT para aprofundar as desigualdades na remuneração? A justificativa da empresa foi a "motivação" dos funcionários. Em 2006, argumenta a empresa, teria havido "[...] pouca motivação para que a ECT atingisse as metas estabelecidas" e "pouca motivação para que a ECT atingisse lucros maiores", e com as mudanças a partir de 2007 seria possível "grande motivação para que a ECT atinja as metas estabelecidas" e também "grande motivação para que a ECT atinja lucros maiores." (ECT, 2007b)

O exercício de 2008 foi exemplar a respeito das consequências dos novos critérios de distribuição da PLR. Para o exercício, estabeleceu-se o montante máximo de 11,9\% dos R\$ 808 milhões de lucros da ECT para distribuição a título de PLR.

Para alguns funcionários, a influência do lucro da estatal sobre a PLR é uma questão controversa:

Não adianta falar em faturamento. Independente do faturamento, a forma de distribuição é que deve ser negociada. Em 2007 foi lucro recorde e olha o que sobrou para nós. Sinto dizer-lhes, mas a PLR 2008 não será muito dife- 
rente. Não é o faturamento, mas a forma justa de distribuição. (Atendente Comercial, dez. 2010)

De acordo com a percepção dos funcionários, o lucro da estatal e as metas estabelecidas não garantem necessariamente uma parcela capaz de satisfazer aos trabalhadores, porque, além de cumprirem as metas, é preciso atentar para os critérios de distribuição da PLR.

Os trabalhadores elegíveis para receber a PLR, pelos critérios propostos pela ECT (2008b), seriam os seguintes: os funcionários que mantiveram vínculo empregatício durante o ano de 2008, mesmo que proporcionalmente aos meses trabalhados; os funcionários desligados "sem justa causa" ou demitidos "a pedido"; os dirigentes da ECT, mesmo que sem vínculo empregatício (como os que exercem funções de livre nomeação e exoneração, como os altos cargos da Administração Central); dirigentes sindicais liberados; aposentados por invalidez; afastados por problemas de saúde; empregadas em licença maternidade e outros casos específicos.

Os critérios estabelecidos para a distribuição da remuneração variável foram divididos em organizacionais e individuais. Assim, parte da PLR seria proporcional ao número de meses trabalhados e dependeria de critérios vinculados ao desempenho dos funcionários, enquanto uma segunda parte dependeria do desempenho das Diretorias Regionais. Ao dividir os critérios em individuais e organizacionais, a ECT instrumentaliza a PLR como ferramenta de gestão e de engajamento dos trabalhadores com os resultados da empresa, seguindo as tendências discutidas por Krein (2009).

Seguindo esse critério, o grupo estratégico teve como meta alcançar lucro líquido superior a $\mathrm{R} \$ 362$ milhões; não apresentar faltas injustificadas; possuir avaliação no Gerenciamento de Competências e Resultados (GCR) ${ }^{38}$ superior a "C"; e estar vinculado a uma diretoria regional com bom desempenho.

38 O Gerenciamento de Competências e Resultados (GCR) é o instrumento de avaliação funcional. São examinadas as metas cumpridas pelos trabalhadores e o suposto comprometimento com a empresa. São atribuídos conceitos aos desempenhos em uma escala que varia de "A" (Excelente) a "E" (Insuficiente). 
Para os funcionários dos grupos tático e operacional os critérios foram os mesmos do grupo estratégico. Já para os funcionários do grupo de execução, os critérios específicos contemplam a existência de lucros, limite no número de faltas injustificadas, avaliação no GCR e desempenho da Diretoria Regional.

Dentre os critérios para os grupos estratégico, tático e operacional para o corpo gerencial da ECT, portanto - estava não só a necessidade de lucros, mas que ele estivesse acima de $\mathrm{R} \$ 362$ milhões para que fizessem jus à remuneração variável. Ao mesmo tempo, os funcionários do grupo de execução tinham como um dos critérios apenas a existência de lucros. Até este ponto, há uma aparente vantagem dos trabalhadores da área operacional com menores remunerações.

No entanto, é preciso considerar que havia entre os critérios de distribuição da PLR para os grupos de funcionários um "fator de risco". O fator de risco foi atribuído aos cargos de gerência, não abarcando, desta forma, nenhum funcionário do grupo de execução. Segundo a ECT, os gerentes são os responsáveis por incrementar os lucros da empresa e, com isso, mereceriam multiplicar os salários básicos por um índice diferenciado e maior, conforme cada função/cargo ocupado na hierarquia funcional. Sendo assim, pelos critérios propostos pela ECT, os funcionários receberiam a PLR segundo o esquema do quadro 7:

QUADRO 7-CRITÉRIOS DE DISTRIBUIÇÃO DA PLR POR HIERARQUIA FUNCIONAL

\begin{tabular}{|l|l|l|}
\hline GRUPOS & PARCELA COM RISCO & PARCELA SEM RISCO \\
\hline Estratégico I & Até $2 \times$ a remuneração média & Não Há \\
\hline Estratégico II & Até $1,5 \times$ a remuneração média & Não Há \\
\hline Estratégico III & Até $1,2 \times$ a remuneração média & Não Há \\
\hline Tático & Até 0,5 $\times$ a remuneração média & Salário+índice de PLR \\
\hline Operacional & Até 0,1 $\times$ a remuneração média & Salário+índice de PLR \\
\hline Execução & Não Há & Salário+índice de PLR \\
\hline
\end{tabular}

Fonte: BRASIL, 2008

Esses critérios de distribuição da PLR resultariam nos seguintes valores para os funcionários de cada grupo: 
TABELA 5 - ADAPTADO DA SIMULAÇÃO DE PAGAMENTO DA PLR CONFORME PRIMEIRA PROPOSTA DA ECT.

\begin{tabular}{|c|c|c|c|c|c|c|c|c|}
\hline \multirow{2}{*}{\multicolumn{5}{|c|}{$\begin{array}{l}\text { Empresa Brasileira de Correios e Telégrafos } \\
\text { Diretoria de Gestão de pessoas } \\
\text { Simulações da PLR 2008/2009 } \\
\text { 1a Proposta da ECT }\end{array}$}} & \multicolumn{2}{|c|}{$\begin{array}{l}\text { Basear Cálculo da } \\
\text { Parcela Sem Risco em: }\end{array}$} & \multirow[t]{2}{*}{$\begin{array}{l}\text { Limites } \\
\text { da PLR }\end{array}$} & \multirow[t]{2}{*}{ Mínimo: 800} \\
\hline & & & & & \multirow{2}{*}{\begin{tabular}{|l|} 
1a \\
Referência \\
Salarian do \\
Cargo $(\mathrm{s} / \mathrm{n})$ \\
NÃO
\end{tabular}} & Remuneração & & \\
\hline & & & & & & Sim & $\begin{array}{l}\text { Valor Total } \\
\text { Pagar: } 95.0\end{array}$ & $\begin{array}{l}\text { da PLR a } \\
00.000,00\end{array}$ \\
\hline Grupos & Efetivo & \begin{tabular}{|l|} 
Totais das \\
Remuneraçōes
\end{tabular} & \begin{tabular}{|l|} 
Fator da \\
Parcela \\
com \\
Risco \\
\end{tabular} & \begin{tabular}{|l|} 
Fator da \\
Parcela \\
sem \\
Risco
\end{tabular} & $\begin{array}{l}\text { Menor PLR } \\
\text { do Grupo }\end{array}$ & $\begin{array}{l}\text { Maior PRL } \\
\text { do Grupo }\end{array}$ & $\begin{array}{l}\text { Média da } \\
\text { PLR do } \\
\text { Grupo }\end{array}$ & $\begin{array}{l}\text { Total da PLR } \\
\text { do Grupo }\end{array}$ \\
\hline Estratégico 1 & 7 & $190.510,46$ & 1,80 & $0,00 \%$ & $48.988,00$ & $48.988,40$ & $48.988,40$ & $342.918,83$ \\
\hline Estratégico 2 & 95 & 1.558.176,52 & 1,30 & $0,00 \%$ & $13.328,60$ & $27.488,92$ & $21.289,17$ & $2.025 .629,48$ \\
\hline Estratégico 3 & 59 & 744.359,94 & 1,00 & $0,00 \%$ & $8.358,90$ & $15.541,02$ & $12.585,75$ & 744.359,94 \\
\hline Tático & 898 & 8.882.271,47 & 0,30 & $46,15 \%$ & 958,95 & $6.626,43$ & $4.068,94$ & 3.659.131,13 \\
\hline Operacional & 15.634 & $50.562 .950,16$ & 0,20 & $46,15 \%$ & 700,00 & $4.132,77$ & $1.179,38$ & 17.711.150,91 \\
\hline Execução 1 & 32.968 & $26.378 .508,26$ & 0,00 & $46,15 \%$ & 700,00 & 700,00 & 700,00 & $23.077 .600,00$ \\
\hline Execução 2 & 31.798 & $37.509 .159,20$ & 0,00 & $46,15 \%$ & 700,00 & 700,00 & 700,00 & $22.258 .600,00$ \\
\hline Execução 3 & 14.734 & 25.797.169,96 & 0,00 & $46,15 \%$ & 700,00 & 700,00 & 700,00 & $10.313 .800,00$ \\
\hline Execução 4 & 9.598 & $21.322 .572,71$ & 0,00 & $46,15 \%$ & 700,00 & 700,00 & 700,00 & $6.718 .600,00$ \\
\hline Execução 5 & 10.564 & $40.878 .864,26$ & 0,00 & $46,15 \%$ & 700,00 & $1.316,05$ & 832,72 & $9.268 .207,76$ \\
\hline $\begin{array}{l}\text { Subtotal de } \\
\text { Execução }\end{array}$ & 99.662 & $151.886 .274,39$ & 0,00 & $46,15 \%$ & 700,00 & $1.316,05$ & 732,11 & 71.636.807,76 \\
\hline Totais & 116.355 & $213.824 .542,94$ & - & $46,15 \%$ & 700,00 & $48.988,40$ & 826,07 & 96.116.998,04 \\
\hline
\end{tabular}

Fonte: FENTECT, 2009.

A proposta inicial da ECT aos trabalhadores possibilitou a comparação dos valores que cada funcionário receberia, como apresentado na tabela 5 .

Pelos critérios da primeira proposta, os valores distribuídos seriam muito díspares, com uma parcela no valor de apenas $\mathrm{R} \$ 700,00$ para quase 100 mil trabalhadores e de mais de $\mathrm{R} \$ 48.000$ mil para os diretores da empresa. Este critério bonificaria de forma desigual os funcionários da ECT, o que repercutiu negativamente entre os trabalhadores e os representantes sindicais.

De acordo com sindicatos dos trabalhadores da ECT,

A proposta de PLR da direção da ECT tira o lucro dos Carteiros, OTT's (operadores de triagem), atendentes e demais trabalhadores para premiar a cúpula da direção da empresa. Eles querem dividir o lucro assim: Para o presidente da ECT, Carlos Henrique Custódio e os seis diretores da empresa, reservaram $\mathrm{R} \$ 48.988,40$ para cada um. Aos 27 diretores regionais querem pagar entre $\mathrm{R} \$ 21.289,17$ e $\mathrm{R} \$ 27.488,92$. Aos 68 chefes de área vão destinar de $\mathrm{R} \$ 13.328,00$ a $\mathrm{R} \$ 21.289,00$. Os 898 gerentes e coordenadores ficam com de $\mathrm{R} \$ 4.068,94$ até $\mathrm{R} \$ 6.626,43$, e para os $\mathrm{SO}$ (super- 
visores de operação), de $\mathrm{R} \$ 1.179,38$ até $\mathrm{R} \$$ 4.132,77. E para os 99.662 trabalhadores, R\$700,00. (SINTECT de SANTA MARIA, 2009, grifo nosso)

A ECT propôs, portanto, uma segmentação entre seus funcionários conforme o cargo e a função que exercem na empresa, impossibilitando a coesão entre os grupos de funcionários. Assim, a ECT mina, como outras empresas, a solidariedade entre os trabalhadores por meio da PLR ao propor uma bonificação desigual. (KREIN, 2009)

Esta primeira proposta foi apresentada pela ECT à Comissão de $\mathrm{Ne}-$ gociação dos Trabalhadores, que não participou - como destaca o ofício 439/2008 do DEST à ECT - da elaboração dos critérios para pagamento da PLR. Assim, a ECT atropelou a legislação federal e o Acordo Coletivo 2008/2009, que garantia aos trabalhadores a participação na definição dos critérios de distribuição da remuneração variável. Com isso, a ECT juntou-se ao grupo de empresas que desrespeitam a legislação ao não negociar o pagamento da PLR e ao impor o pagamento do bônus de forma unilateral. (ARAÚJO; CARTONI; JUSTO, 2001)

Diante disto, em janeiro de 2009, a FENTECT agendou reunião com o DEST para tratar de diversos assuntos relacionados aos Correios, dentre eles a PLR. Os dirigentes da Federação questionaram a ausência de representantes dos trabalhadores na comissão que estabeleceu os critérios de distribuição da PLR e a "total discordância" com a proposta. Segundo a FENTECT, os representantes do DEST informaram que somente definiam os parâmetros, cabendo à ECT e ao sindicato a negociação. Para o DEST, a ECT informou que os sindicatos não quiseram participar das negociações e, por isso, a empresa teria apresentado sua proposta de forma unilateral. Assim, caso houvesse alguma negociação, o DEST acataria as mudanças. Segundo a FENTECT, era preciso buscar uma "negociação onde o lucro seja de fato dividido de forma igualitária entre todos os trabalhadores." (FENTECT, 2009b)

Com a retomada das negociações e estabelecimento do critério mínimo de $\mathrm{R} \$ 700,00$ para os trabalhadores do grupo operacional, conforme recomendação do DEST, a ECT solicitou à FENTECT avaliação da proposta junto aos sindicatos da categoria, mesmo a Federação alegando ser contrária a uma distribuição não linear dos valores. Diante disto, a FENTECT 
mobilizou a base sindical para participar das assembleias e das negociações. Como resultado das assembleias dos trabalhadores realizadas em todo o país no dia 3 de março de 2009, a proposta da ECT foi recusada.

Uma moção de repúdio do sindicato de Juiz de Fora/MG expressa a percepção sobre a proposta:

[...] a proposta apresentada é indecorosa, injusta e afronta todos os trabalhadores da classe quando fica claro o desrespeito com a categoria e a falta de vontade da direção da empresa em remunerar de forma justa os verdadeiros responsáveis pelo vultoso lucro auferido a cada balanço, resultado alcançado sob metas exageradas e sacrifício dos trabalhadores. (SINTECT apud TEIXEIRA, 2012)

A proposta inicial da ECT foi repudiada pela maior parte dos sindicatos associados à FENTECT, o que impôs a necessidade de se restabelecer as negociações entre a Comissão da ECT e os representantes dos trabalhadores.

Em decorrência do impasse em relação à primeira proposta, a Comissão de Negociação da FENTECT foi convidada pela ECT a participar de uma reunião para negociação. Nessa ocasião, foi apresentada uma segunda proposta pela ECT - oficializada dias depois -, que pode ser visualizada na tabela 6 :

TABELA 6 - 2A PROPOSTA DE PLR EM 2008

\begin{tabular}{|c|c|c|c|c|c|c|c|c|}
\hline & \multirow{3}{*}{$\begin{array}{l}1 \text { o } \\
\text { Referencial } \\
\text { Salarial do } \\
\text { Cargo (s/n) } \\
\text { Ñ̃O }\end{array}$} & & \multirow{2}{*}{$\begin{array}{l}\text { Limites } \\
\text { da PLR }\end{array}$} & \multirow[b]{2}{*}{$\begin{array}{l}\text { Máximo: } \\
\text { 40.823,67 }\end{array}$} \\
\hline \multicolumn{5}{|c|}{ Simulação da PLR 2008/2009 } & & Remuneração & & \\
\hline & & & & & & Sim & \multicolumn{2}{|c|}{$\begin{array}{l}\text { Valor Total da PLR a } \\
\text { Pagar: } 95.000 .000,00\end{array}$} \\
\hline Grupos & Efetivo & $\begin{array}{l}\text { Total } \\
\text { Remuneração } \\
\text { (RM sb+fun) }\end{array}$ & $\begin{array}{l}\text { Fator da } \\
\text { Parcela } \\
\text { com Risco }\end{array}$ & $\begin{array}{l}\text { Fator da } \\
\text { Parcela } \\
\text { sem Risco }\end{array}$ & $\begin{array}{l}\text { Maior PLR } \\
\text { do Grupo }\end{array}$ & $\begin{array}{l}\text { Média da PLR } \\
\text { do Grupo }\end{array}$ & $\begin{array}{l}\text { Total da } \\
\text { PLR por } \\
\text { Grupo }\end{array}$ & \\
\hline Estratégico 1 & 10 & $247.302,74$ & 1,50 & $0,00 \%$ & $40.823,67$ & $40.823,67$ & $40.823,67$ & $370.954,11$ \\
\hline Estratégico 2 & 146 & $2.205 .732,74$ & 1,00 & $0,00 \%$ & $10.252,77$ & $21.145,32$ & $16.376,28$ & $2.205 .732,47$ \\
\hline Estratégico 3 & 79 & $905.623,14$ & 0,80 & $0,00 \%$ & $6.687,12$ & $12.432,82$ & $10.068,00$ & $724.498,51$ \\
\hline Tático & 1.134 & $10.546 .415,50$ & 0,60 & $0,00 \%$ & $1.319,66$ & $10.620,77$ & $5.972,04$ & $6.327 .849,30$ \\
\hline Operacional & 89.937 & $51.430 .079,57$ & 0,30 & $0,00 \%$ & 900,00 & $4.225,09$ & $1.399,01$ & $11.992 .915,91$ \\
\hline Execução & 89.937 & $123.180 .630,81$ & 0,00 & $0,00 \%$ & 800,00 & 800,00 & 800,00 & $71.949 .600,00$ \\
\hline Totais & 108.375 & $188.515 .784,23$ & & $0,00 \%$ & & & & $93.571 .550,31$ \\
\hline
\end{tabular}

Item 1 - As faltas não justificadas incidirão sobre a parcela variável, na proporção de 10\% para cada falta, único critério a ser aplicado;

Item 2 - A parcela fixa corresponderá a 80\%;

Item 3 - A parcela variável corresponderá a $20 \%$. 
Pela nova proposta da ECT, os trabalhadores enquadrados no Grupo de Execução ganhariam agora $\mathrm{R} \$ 800,00$. No entanto, pelos critérios estabelecidos, o valor a ser pago não seria de $\mathrm{R} \$ 800,00$, mas $\mathrm{R} \$ 640,00$. Isto porque $80 \%$ do valor seria pago de forma linear e $20 \%$ de acordo com as faltas injustificadas de cada funcionário. Em outras palavras, uma parcela seria linear e outra condicionada ao índice de absenteísmo de cada trabalhador. Assim, a parcela a ser paga sofreria um decréscimo de $10 \%$ para cada falta injustificada. Com isto, o trabalhador que tivesse duas faltas durante o ano perderia $20 \%$ da parcela variável. Dessa maneira, a ECT vinculou o valor a pagar aos índices de absenteísmo, como tem sido feito desde a década de $1990 \mathrm{em}$ empresas privadas. (ARAÚJO; CARTONI; JUSTO, 2001; CARVALHO NETO, 2001)

Assim, enquanto a direção da estatal - cargos estratégicos - ganharia uma PLR média acima de $\mathrm{R} \$ 10.000$ - chegando ao montante de $\mathrm{R} \$$ 40.000 -, funcionários da execução ganhariam, no máximo, R\$ 800,00. Uma diferença mínima de $1.250 \%$, reiterando as desigualdades das bonificações de PLR.

Mesmo com a segunda proposta, a insatisfação dos trabalhadores da ECT manteve-se. Segundo a Comissão de Negociação da PLR da FENTECT, era preciso continuar "denunciando a indignação dos trabalhadores e trabalhadoras quanto à disparidade dos valores pagos aos grupos estratégicos da ECT em relação ao menor valor". De acordo com a FENTECT, diante das diversas reclamações dos trabalhadores a parlamentares, o presidente da ECT foi convocado para prestar esclarecimentos à Comissão de Trabalho da Câmara dos Deputados, no dia 19 de março de 2009, sobre as negociações trabalhistas envolvendo a PLR.

Novamente não houve entendimento nas negociações com a ECT e a proposta foi encaminhada aos sindicatos de base para avaliação em assembleias realizadas no dia 31 de março, sendo rejeitada por 22 dos 35 sindicatos filiados à FENTECT, inclusive com indicativo de greve caso a proposta não fosse alterada.

Apesar de os sindicatos terem rejeitado em assembleias a proposta, a empresa encaminhou-a para aprovação do DEST e informou às Diretorias Regionais que aguardaria apenas o aval do órgão para iniciar os pagamentos. Diante disso, a FENTECT informou que lamentava a 
[...] postura da empresa, que abandonou as negociações e tenta fazer valer a sua imposição de pagamento de uma PLR com discrepância absurda, onde a Direção vai receber R 40 mil e os trabalhadores de nível básico receberão até $\mathrm{R} \$ 800$. Reafirmamos que a Comissão Permanente da FENTECT continua à disposição para continuar as negociações conforme deliberação das assembleias do dia 31/04/09. (FENTECT, 2009c)

Mesmo sem acordo com os sindicatos, a ECT iniciou o pagamento dos valores correspondentes a cada funcionário ainda no mês de abril de 2009. Com isso, a empresa novamente se alinhou ao grupo de empresas que pagaram a PLR sem acordo ou negociação com os trabalhadores. (ARAÚJO; CARTONI; JUSTO, 2001)

Mesmo com o pagamento de forma unilateral pela ECT, denúncias em relação a valores recebidos chegaram aos sindicatos. Nesse sentido, a FENTECT questionou a ECT acerca de casos como o não pagamento das parcelas de alguns trabalhadores; quantias inferiores aos mínimos estipulados; e até casos de funcionários que receberam valores inferiores por apresentarem atestado médico e supostas faltas injustificadas. (TEIXEIRA, 2012)

Em ofício enviado ao DEST, a FENTECT apresenta um breve relato sobre o histórico das negociações em torno da PLR, importante para se apreender as percepções dos sindicatos:

A história da Participação nos Lucros paga pelos Correios é um capítulo à parte nos processos de negociação na Empresa Brasileira de Correios e Telégrafos. Cabe aqui destacar que a lei que regulamenta o pagamento da Participação nos Lucros é de 2000, e que somente em 2003 recebemos nossa primeira Participação nos Lucros.

Porém, em que pese o pagamento desta, desde 2003, somente em 2006 o Movimento Sindical conseguiu de fato negociar e fechar um acordo com a Direção dos Correios. Depois disto, em 2007 nos reunimos com a Direção dos Correios, porém, não chegamos a um acordo.

Em abril de 2008, com o maior lucro da história dos Correios, o pagamento da Participação nos Lucros foi um dos episódios mais vergonhosos da história dos Correios. Apesar de a empresa ter tido um lucro de $65 \%$ maior [sic] que no ano anterior, o valor recebido pelos 
trabalhadores foi muito menor. Enquanto os valores recebidos pelas pessoas de cargos gerenciais foi muito maior, chegando ao absurdo de alguns receberem até $R \$ 40$ mil reais e os trabalhadores de base receberam $\mathrm{R} \$ 145,00$ reais [sic].

Este pagamento causou profunda indignação nos trabalhadores, o que motivou, juntamente com outras reivindicações, a greve da categoria, onde no final chegou-se a um acordo de revisão, que aliás nunca foi feita [sic].

O que nos assusta é que apesar de todo episódio do ano passado, é que a empresa [sic] não chamou sequer os trabalhadores para a negociação da Participação nos Lucros/2008, que será paga este ano, deixando os trabalhadores apreensivos e mobilizados contra o que seria a reedição da PLR paga no ano passado.

Neste sentido, queremos deixar claro a este órgão que no ano de 2008 não houve nenhuma negociação com os trabalhadores e tampouco sabemos quais serão os critérios. Estamos solicitando a abertura da negociação para o pagamento da PLR/2008, para que de fato a empresa passe a cumprir a Lei 10.101 de 2000, onde existe a necessidade de negociação com os trabalhadores. (FENTECT apud TEIXEIRA, 2012)

Apesar dos questionamentos, a FENTECT não disponibilizou aos trabalhadores mais esclarecimentos em seus informes sobre a PLR 2008, não tornando claros os desdobramentos dos supostos critérios "estranhos", ou mesmo mobilizando a categoria contra o pagamento unilateral da PLR.

A tendência da PLR nos Correios reitera aspectos já constatados em outras corporações. Segundo Krein (2007), que analisou dados recentes acerca das tendências da remuneração variável, as principais disputas em torno da PLR extrapolam a simples questão do bônus, mas abarcam também diversos outros aspectos, como:

(1) a forma de distribuição equânime ou proporcional ao salário, com a tendência de crescimento de um bônus desigual; (2) o estabelecimento de metas e as condições para cumpri-las; (3) a não substituição de parcelas fixas do salário por PLR; (4) a partilha dos ganhos de produtividade, de forma a não ser somente um indicador de PLR, mas incorporando-se aos salários [...]. (KREIN, 2009, p. 37) 
Diante das disputas com a ECT, no exercício seguinte a FENTECT passaria a propor uma PLR linear, dividindo igualmente os resultados entre todos os funcionários. Houve, inclusive, a propagação, pela entidade sindical, de uma conversa com o diretor de recursos humanos da ECT em que este, supostamente, teria dito que em 2010 não haveria PLR. A ECT tratou de desmentir as informações e, posteriormente, as negociações começaram com acompanhamento de um procurador do trabalho.

De acordo com a FENTEC, a primeira proposta da ECT era semelhante à de 2009, sendo a proposta rejeitada e o valor linear de $\mathrm{R} \$ 2.000,00$ apresentado como alternativa. (FENTECT, Informe 017, 11 maio 2010)

Segundo a FENTECT,

[...] desde 2008 a empresa adotou uma vergonhosa prática de pagar a PLR, não só unilateral como PLR de 40 mil reais para os altos cargos na empresa, excluindo os trabalhadores em situação de: gestante, acidentes de trabalho, auxilio doença [sic], suspensão, etc. Tal prática tinha o objetivo de sobrar mais dinheiro para pagar melhor o corpo diretivo da empresa e seus braços nas regionais. Assim foi em 2008, 2009 e 2010 [sic]. (FENETECT, Informe 023, 14 abr. 2001)

Pela análise da FENTECT, verifica-se que a entidade sindical esteve em posição desfavorável até 2010 ao negociar a PLR. Os critérios para inclusão e exclusão dos trabalhadores da remuneração variável não eram considerados os mais justos e provocavam distorções que revelavam até mesmo a discriminação dos trabalhadores por gênero na distribuição da PLR ao não garantir plenamente o recebimento às trabalhadoras gestantes ou em licença maternidade.

Em 2010, a FENTECT buscou novamente melhorar as condições das negociações pela mudança na presidência da República e a transferência do comando do Ministério das Comunicações do PMDB para o PT. Nas primeiras reuniões com os Correios, a FENTECT considerou favorável até o compromisso da empresa em não pagar a PLR caso não houvesse acordo. Ao longo do ano, depois de três meses de negociações, a ECT apresentou nova proposta de PLR que seria aceita e repetida, com algumas alterações, em 2011, e que, no entender da FENTECT, apresentou 
ganhos e avanços para os trabalhadores. A empresa, inclusive, tentou vincular o exercício de 2010 e 2011, proposta que foi rejeitada.

O acordo de PLR de 2010, de acordo com a FENTECT, apresentou ganhos importantes, embora parciais:

[...] a FENTECT buscou inserir o máximo de pessoas que foram excluídas durante estes últimos anos. Neste quesito entendemos que conseguimos fazer com que a proposta corrigisse injustiças que vinham sendo cometidas, como o pagamento para trabalhadoras em licença gestante; ao trabalhador acidentário do trabalho [sic]; aos trabalhadores em lei de greve; e trabalhadores em licença adoção.

Em outros critérios entendemos que houve avanço parcial, mas que possibilita a inclusão de mais companheiros, como: prolongar o pagamento em 180 dias para o trabalhador em licença médica;

Suspensão - Perda de 25\% a cada dia suspenso, neste critério cabe lembrar que nas PLR's passadas os trabalhadores perdiam todos os valores.

A adoção do critério 30\% corporativo também garante um pagamento mínimo de PLR a todos os trabalhadores, sem critérios individuais. A inclusão de um teto máximo é entendida como um avanço nas negociações, o que se contrapõe aos 40 mil reais que a alta direção vinha recebendo, não sendo ainda nossa reivindicação que é de linearidade, mas um grande avanço em relação ao praticado até então pela ECT, próximo ao praticado em outras empresas [sic].

[...] Neste sentido, nossa orientação é pela aprovação da proposta apresentada pela empresa para o ano de 2010, de critérios e com o valor mínimo de $\mathrm{R} \$ 880,00$ e teto máximo de 5 vezes o valor mínimo, por entender que sob a ótica das leis que regem a PLR estamos no limite máximo, ou seja, batemos o teto [sic]. (Informe 023 da FENTECT apud TEIXEIRA, 2013)

Observa-se que depois do acordo de PLR de 2006 a FENTECT só voltou a firmar acordo com a ECT em 2010, repetindo tal feito em 2011. Neste último ano, a entidade sindical considerou que o principal avanço nas negociações foi a retirada, por parte da ECT, da avaliação individual como critério de elegibilidade para os trabalhadores que receberiam a remuneração variável - como a estatal havia apresentado nas negociações. 
Em 2011, a parcela mínima de PLR foi fixada em R \$880,00. Apesar do estabelecimento de um limite entre o menor e maior valor da PLR, a insatisfação entre os funcionários arrefeceu muito pouco, sobretudo pelo baixo valor recebido pelos funcionários de nível operacional.

Há um descompasso, portanto, entre o entusiasmo dos sindicalistas e o desânimo dos trabalhadores que pode ser explicado a partir dos baixos valores recebidos a título de participação nos lucros e resultados. A incompreensão sobre os critérios de distribuição dos lucros também interfere nesse processo, porque o lucro da estatal é compartilhado entre dividendos ao governo, a parcela da empresa e o que finalmente é autorizado a ser distribuir aos trabalhadores. Assim, apesar dos lucros crescentes da ECT, eles não podem ser comparados aos de outras estatais que proporcionam maiores bonificações aos seus trabalhadores por terem maior lucratividade em suas atividades, o que restringe bastante os valores a distribuir entre os trabalhadores dos Correios.

\section{SINDICALISTAS E GESTORES: PROXIMIDADE NOS ANOS 2000}

A Articulação Sindical, grupo ligado ao PT, foi a corrente com mais força política entre os trabalhadores dos Correios durante o governo Lula. Além dela, a Central dos Trabalhadores e Trabalhadoras do Brasil (CTB), vinculada ao Partido Comunista do Brasil (PC do B), o Movimento de Resistência e Luta dos Trabalhadores dos Correios (MRL) - que se proclama independente de partidos políticos -, a CONLUTAS, o Movimento Sindical de Base (MSB), a Alternativa Sindical Socialista (ASS) e a corrente Ecetistas em Luta (Partido da Causa Operária) se destacam como principais forças políticas no meio sindical entre os trabalhadores dos Correios.

Os postos de direção na FENTECT são ocupados de forma proporcional, para que as decisões sejam colegiadas. Contudo, o grupo que ocupa a maioria das vagas, evidentemente, dispõe de condições para que suas propostas sejam predominantes.

Apesar da proximidade entre a Articulação Sindical e o governo Lula, as mobilizações da FENTECT durante os anos 2000 foram intensas, inclusive com greves durante todo o governo Lula, com exceção de 2004. 
As greves ocorridas durante o período reivindicavam, quase sempre, reajustes salariais e dos valores dos benefícios. Entre 2003 e 2009, segundo a empresa, os ganhos dos trabalhadores foram de 193,96\%, acima do índice de preços ao consumidor amplo (IPCA), que foi de $46,03 \%$. Comparando com os anos do governo FHC, foram ganhos salariais consideráveis, sobretudo porque houve perda do poder de compra dos trabalhadores durante a década de 1990. (MEDINA, 2009) Apesar desses índices gerais, o reajuste no salário depende da "referência salarial" de cada funcionário.

Questionado pela Folha de São Paulo sobre o número de greves no governo Lula, José Rivaldo, secretário geral da FENTECT à época (outubro de 2009), declarou: "Não acredito que as greves estejam sendo banalizadas. É o instrumento que a gente tem, e muitas vezes elas acontecem por conta de falta de habilidade da empresa." (MEDINA, 2009)

Diante da grande incidência de greves, o governo federal planejou, por meio do Gabinete de Segurança Institucional, restringir o direito de greve nos Correios por meio do enquadramento do setor postal como "área essencial", criando instrumentos para limitar a mobilização dos trabalhadores durante movimentos paredistas. Contudo, a necessidade de alterar a legislação em vigor para enquadrar os Correios como área essencial tem impedido o governo de implementar o plano. (GOVERNO..., 2009)

As greves e mobilizações, contudo, não eliminam a proximidade entre sindicalistas e gestores na ECT. A ocupação de cargos de chefia e gestão por sindicalistas foi apontada como fator de enfraquecimento das reivindicações por diversos trabalhadores durante a pesquisa.

A estimativa, que deve ser ponderada porque feita por uma corrente de oposição - CONLUTAS -, é que mais de 700 sindicalistas tenham ocupado cargos na empresa até meados de 2011. A crítica é corroborada por órgãos dos profissionais de nível técnico e superior, a ADCAP, para quem a ECT passou por um processo de "desprofissionalização" e por um "aparelhamento político"; 39 contudo, parte das críticas da ADCAP

39 Nota veiculada pela ADCAP em seu site na internet em 17 de maio de 2011. 
também se fundamenta pelo recorte hierárquico, porque muitos dos ex- sindicalistas - que em sua maioria ingressou na empresa como carteiro e operador de triagem e transbordo - estavam ocupando posições táticas e estratégicas em detrimento dos funcionários de nível superior.

O trânsito de sindicalistas para a gestão é identificado desde o nível operacional - com a indicação de sindicalistas para cargos de chefia em agências e centros de distribuição - até o nível estratégico da empresa, nos mais altos escalões. Nesse sentido, o exemplo recorrente entre os trabalhadores é o do ex-secretário geral da FENTECT, Manoel Cantoara, que foi designado em 2009 para ocupar o cargo de coordenador da Comissão Permanente de Relações do Trabalho da ECT. No mesmo ano, durante a greve dos trabalhadores, ele participou das negociações como representante da empresa e não mais dos trabalhadores. O fato de ele ser da Articulação Sindical, mesma corrente que a maioria dos integrantes da Direção Colegiada da FENTECT, é apontado pelos trabalhadores e por alguns sindicalistas como fator determinante para o desfecho da greve de 2009, quando a proposta do governo foi aceita, inclusive com a imposição aos trabalhadores do primeiro acordo coletivo bianual da categoria, o que enfraqueceu as mobilizações em 2010 - ano de campanha eleitoral. $\mathrm{O}$ acordo bianual, inclusive, foi uma proposta da empresa, que na figura de seu presidente, afirmou: "Queremos um acordo bianual para sair dessa questão de greve todos os anos." (COSTA..., 2009)

Ao tratar do tema com um sindicalista da Articulação Sindical, ele expôs como a proximidade entre sindicato, partido e empresa pode ser justificada por um viés ideológico: "Temos uma base que também recebe cartas e encomendas e participa da vida econômica, e nosso compromisso é integral com o trabalhador". Para o sindicalista, isso implica "assumir posições de comando na sociedade e na empresa". A posição do partido (PT), para ele, é ocupar os espaços possíveis por um comprometimento ideológico. Mas tal proximidade tem favorecido os trabalhadores? "Na hora que o companheiro assume na empresa, aí ele está do lado dos negócios da empresa". "O problema é que tem camarada que usa todo seu conhecimento como sindicalista para desmobilizar a categoria agora que é gestor. Agora, estamos do lado dos trabalhadores". 
Diante desses elementos, observa-se que durante o governo Lula as mobilizações dos trabalhadores dos Correios foram intensas e com conquistas para a categoria. Contudo, a proximidade entre sindicalistas e gestores ainda é motivo de desconfiança por parte das bases, que nem sempre identificam o interesse da categoria com a ocupação de cargos de gestão por ex-sindicalistas, a despeito do suposto compromisso ideológico com os trabalhadores que afirmam ter.

Na próxima seção, as políticas de gestão de pessoas na ECT são analisadas com um recorte de gênero, buscando compreender não só como as estratégias de gestão possuem um viés de gênero, mas também as relações entre os trabalhadores e trabalhadoras.

\section{O TRABALHO FEMININO NOS CORREIOS: CONSIDERAÇÕES SOBRE AS RELAÇÕES DE GÊNERO NAS POLÍTICAS DE GESTÃO}

A composição da força de trabalho da ECT mostra como homens e mulheres estão distribuídos nos cargos e na estrutura hierárquica da empresa.

Os empregados da ECT em abril de 2013 totalizavam 119.971 funcionários, dos quais 23,12\% eram mulheres, isto é, 27.736 trabalhadoras. Isso mostra que a composição sexual da força de trabalho nos Correios não se altera desde o primeiro ano do governo Lula, quando a taxa era de quase $23 \%{ }^{40}$

$\mathrm{Na}$ Europa, a participação feminina no setor postal e de telecomunicações é de cerca de $30 \%$, o que mostra a baixa participação das mulheres no setor também no contexto internacional - evidenciando ser a área bastante masculinizada.

O baixíssimo índice de participação das mulheres na força de trabalho dos Correios pode ser mais bem apreendido ao se observar a distribuição por sexo dos trabalhadores que exercem atividades operacionais diretamente relacionadas às atividades finalísticas da empresa, isto é, os cargos de atendente comercial, operador de triagem e transbordo e carteiro:

40 Em 2003 as mulheres representavam quase 22\% da força de trabalho, atingindo 22,5\% no ano seguinte. 
TABELA 7 - SEXO DOS OCUPANTES DO CARGO DE AGENTE DE CORREIOS POR ATIVIDADE (MAIO 2010) ${ }^{41}$

\begin{tabular}{|l|l|l|l|l|l|l|}
\hline Agente de Correios & \multicolumn{2}{l|}{ Homens } & \multicolumn{3}{l|}{ Mulheres } & \multicolumn{2}{l|}{ Total } \\
\hline Carteiro/a & 50.396 & $89,93 \%$ & 5.642 & $10,07 \%$ & 56.038 & $100 \%$ \\
\hline Atendente & 12.246 & $54,05 \%$ & 10.410 & $45,95 \%$ & 22.656 & $100 \%$ \\
\hline Operador de triagem e transbordo & 10.004 & $77,43 \%$ & 2.916 & $22,57 \%$ & 12.920 & $100 \%$ \\
\hline Total do efetivo & & & & & & \\
\hline
\end{tabular}

Fonte: Elaborado pelo autor.

Verifica-se pelos números apresentados na Tabela 7 uma distribuição desigual da participação de homens e mulheres nas atividades da área operacional. Em números absolutos, os homens compõem quase $67 \%$ do efetivo operacional, enquanto as mulheres somam pouco mais de $17 \%$ (o restante dos trabalhadores e trabalhadores está distribuído por cargos administrativos - atividade suporte).

Ao se analisar por atividade a distribuição de trabalhadores e trabalhadoras, constata-se a concentração de homens nos cargos de carteiro e operador de triagem e transbordo, ou seja, a presença de $89 \%$ e $77 \%$, respectivamente, de homens nesses cargos. Somente a atividade de atendente comercial que possui uma participação maior de mulheres, correspondendo a quase $46 \%$ do total.

Imagens de gênero e relações sociais de sexo: análise da atividade de carteiro

Como compreender os números tão discrepantes de homens e mulheres na atividade operacional da ECT? Para responder a questão, é preciso considerar como as relações sociais de sexo e as imagens de gênero têm influenciado a participação das mulheres no mercado de trabalho.

Nesse sentido, faz-se necessário observar e compreender que as relações sociais de sexo são institucionalizadas nas dinâmicas pessoais e nas condutas utilizadas para a ação social. As relações sociais de sexo, como ensina Kergoat (2009), derivam de construções sociais e não de

41 Utilizo informações de maio de 2010 porque só obtive informações sobre a distribuição dos profissionais na hierarquia profissional por sexo até essa data. Sobre isso, ver Tabela 8. 
supostas "essencialidades" biológicas. Isso implica, portanto, na necessidade de considerar a tensão e o antagonismo existente entre os grupos sociais formados por homens e mulheres.

Nesse sentido, ressalta Kergoat (2007), as relações sociais de sexo são atravessadas por uma hierarquização entre os sexos, caracterizando uma relação de dominação e de poder. As relações sociais de sexo atravessam todas as relações sociais, não se referindo unicamente à esfera do trabalho. No entanto, essas relações possuem uma base material, fundada na divisão do trabalho. ${ }^{42}$ Em razão disso, o trabalho e suas divisões expressam a tensão existente na sociedade em decorrência das relações sociais de sexo.

As relações sociais de sexo e a divisão sexual do trabalho, segundo Hirata (2009), são indissociáveis porque formam um "sistema" que permite compreender as relações sociais assimétricas, desiguais e hierarquizadas entre homens e mulheres.

Nas relações de gênero instituídas no Brasil, a mulher é destinada à função de cuidar do universo doméstico e privado, espaço que socialmente é considerado inferior e onde não se reconhece o valor das atividades realizadas, o que restringe o tempo e os recursos das mulheres para investirem na sua própria capacitação e em trabalhos remunerados. Em consequência disso, o trabalho da mulher na sociedade seria pouco valorizado, tanto econômica quanto socialmente.

Dessa maneira, as imagens de gênero existentes na sociedade, conforme analisa Abramo (2007), seriam responsáveis pela orientação de ações "dicotomizadoras" e hierarquizantes das relações entre homens e mulheres, que garantiriam a manutenção e reprodução das desigualdades de gênero, incluindo aí o mundo do trabalho. ${ }^{43}$

42 A divisão sexual do trabalho é um importante parâmetro para analisar as relações sociais de sexo. Como divisão sexual de trabalho, segue-se, aqui, dentre as alternativas teóricas e conceituais a respeito do assunto, a conceituação de Hirata (2009), que aponta para o conflito, a opressão e dominação presentes nessa divisão. Esse tipo de divisão social, que também é técnica, possui uma "consubstancialidade" de classe e raça/etnia. De acordo com a autora, faz-se necessário ter em tela que a divisão sexual do trabatho é hierarquizada (com o trabalho masculino sempre com maior valor em relação ao trabalho feminino) e comporta a separação entre o trabalho masculino e feminino, que seriam distintos e separados.

43 Após intensa luta dos movimentos feministas a partir da década de 1960, observou-se uma crescente inserção das mulheres no mercado de trabalho que precisa ser compreendida também, como nos mostra Araújo (2004, p.4), a partir de processos como "as mudanças econômicas e demográficas, a intensifica- 
Com isso, como mostra Araújo (2004), "[...] a segmentação das ocupações por sexo é [...] recriada ao longo do processo de reestruturação produtiva [...]", sendo que "as mudanças no sistema de produção têm requerido das mulheres uma série de habilidades que, adquiridas através do seu processo de socialização no espaço privado, apelam para um reforço de comportamentos culturalmente definidos como femininos." (ARAUJO, 2004, p. 9, grifo do autor)

Esses aspectos nos remetem à análise de Abramo (2007) sobre a inserção da força de trabalho das mulheres no mercado de trabalho como uma força de trabalho secundária, ou seja, não sendo considerada a principal renda da família, já que as relações sociais de sexo na sociedade atribuem o papel de provedor ao homem, que teria a responsabilidade de possuir a maior renda, ou única, da unidade familiar, enquanto à mulher caberia o papel de cuidar das atividades domésticas e de reprodução, participando das atividades produtivas apenas de forma a complementar a renda principal da família. De forma secundária, portanto.

As relações sociais de sexo, logo, influenciam as relações de trabalho e as condições de inserção da mulher nas atividades produtivas. Ao mesmo tempo em que estrutura as relações sociais, a ordem de gênero condiciona as imagens de gênero presentes na sociedade, responsáveis pela atualização das desigualdades entre homens e mulheres.

Nessa direção, a ECT nos informa, por exemplo, que a atividade de carteiro foi considerada até recentemente uma "atividade masculina", apesar da crescente participação das mulheres. A presença de mulheres no cargo remonta ao ano de 1992, quando houve o questionamento da proibição das mulheres em participar da seleção externa para carteiro e as barreiras foram derrubadas. Na ocasião, apenas dezessete mulheres ingressaram na empresa como carteiras. Em 2004, as mulheres já somavam 10\% do total de carteiros, o que representava 4.700 trabalhadoras. (IMPORTÂNCIA...,

ção dos intercâmbios internacionais bem como das mudanças culturais e nos valores relativos ao papel da mulher na sociedade, impulsionadas pelas lutas feministas desde os anos 1970 [...]”. Ainda de acordo com esta autora, desde o início da década de 1980 a inserção feminina no mercado de trabalho remunerado tem passado por mudanças significativas, período em que se começou a falar de feminização do mercado de trabalho. 
2004) O percentual atual é o mesmo, portanto, desde 2004, com pequena variação nos números absolutos (evolução de 4.700 para 5.642 trabalhadoras - maio de 2010).

Verifica-se com base nos números que a atividade de carteiro esteve associada a uma tarefa masculina por estar vinculada a atributos supostamente masculinos, como a força física necessária ao desempenho das atividades do cargo (permanecer em pé em longas jornadas de trabalho, percorrer longas distâncias, realizar esforços físicos ao carregar a bolsa etc.). De forma semelhante, a atividade de operador de triagem e transbordo é considerada a priori uma atividade masculina por estar associada, principalmente, ao transporte de caixas com correspondências, carregamento e descarregamento de caminhões etc. (TEIXEIRA, 2015)

Em 1992, quando pela primeira vez as mulheres participaram da seleção externa para o cargo de carteiro, a Folha de São Paulo acompanhou a trajetória da primeira mulher da região do $\mathrm{ABCD}$ paulista a participar do concurso:

Carla Allan, 24, causou espanto na última quinta-feira, quando resolveu enfrentar uma longa fila e fazer inscrição para o concurso de carteiro. Os motivos que levaram a estudante a optar pela profissão são claros para ela: receber um salário razoável que lhe permita continuar os estudos. [...] Caso passe no concurso, [...] Carla será a primeira 'carteira' do ABCD. 'E possivelmente até do Brasil, porque um funcionário de São Paulo me disse que os Correios já fizeram uma experiência com mulheres que não deu certo', disse. Uma vez aprovada, Carla enfrentará uma jornada de seis horas carregando uma mala de cartas de até 25 quilos. 'Já trabalhei com vendas de imóveis de casa em casa, as duas coisas são parecidas', afirmou. Para ela, o peso não é empecilho. 'Faço musculação e ginástica há nove anos, estou preparada fisicamente'. Problema mesmo, segundo ela, será trabalhar a pé, sujeita às mudanças do tempo. Para evitar outros problemas, antes de fazer a inscrição, Carla ligou para a regional dos Correios em São Paulo para perguntar se aceitavam mulheres e teve resposta positiva. Em Santo André, onde se inscreveu, a coisa não foi bem clara. A princípio, segundo Carla, os funcionários não sabiam o que fazer, mas acabaram aceitando a inscrição. Entre o desconhecimento dos funcionários e a ironia dos concorrentes, Carla saiu vitoriosa, com a inscrição na mão. A estudante se considera capacitada para o exame. [...]. Além disso, ela afirma que está determinada a iniciar 
a carreira. 'Não sei bem o que é, mas tem algo além do dinheiro, é uma profissão interessante', disse. A família de Carla, que mora em Ribeirão Pires, segundo ela, não se assustou com a idéia. A irmã mais nova só não se inscreveu porque não tinha como conciliar os horários da escola e de cuidar da filha. Os amigos também não estranharam a decisão de Carla. 'Acho que não haverá discriminação. No início, todo mundo acha meio esquisito, mas depois vê que não tem nada de errado', afirmou. O importante agora, segundo ela, é se preparar para o exame e passar. 'Não tenho nem namorado para atrapalhar que eu faça minha vida agora', disse. (SALÁRIO ...., 27 jan. 1992, p. 8, grifo nosso)

No dia 15 de julho de 1992, a Folha de São Paulo publicou novamente uma nota sobre Carla:

A primeira carteira do $\mathrm{ABCD}$ [...], a única mulher a executar esse trabalho [...]. O fato de a profissão de carteiro ser desempenhada apenas por homens não impediu que Allan se inscrevesse para o concurso da ECT. 'Quando fui fazer a inscrição, a funcionário recebeu a minha ficha e ficou espantada', disse. [...] O Administrador-postal da ECT [...] que coordena o Centro de Distribuição Domiciliar [...] afirmou que a carteira tem realizado um bom trabalho. 'Os moradores estão gostando. Eles dizem que a mulher é mais cuidadosa.' (CARTEIRA..., 15 jul. 1992)

As duas matérias são ricas na apresentação das relações sociais de sexo e, especialmente, na descrição das imagens de gênero acerca das mulheres, e especificamente sobre a primeira mulher da região a ser carteira. O pioneirismo de Carla como a primeira carteira da região em 1992 foi suficiente para que uma jovem mulher tivesse sua trajetória profissional acompanhada em seus primeiros dias na profissão por um dos maiores jornais do país.

As atitudes e comportamentos relatados mostram como as relações sociais de sexo que reiteram a hierarquia de gênero das atividades exercem enorme pressão sobre a candidata. A candidata rompeu com as expectativas sociais e se aventurou em uma profissão masculinizada. Pela "ousadia" em tentar se inscrever no concurso, "causou espanto". Foi tamanho o "espanto" ao ponto de os funcionários ficarem "sem saber o que fazer" e a situação provocar a "ironia dos concorrentes" por meio de piadas e "brincadeiras" discriminatórias. 
Dessa maneira, as imagens de gênero estavam atuando ao ponto do ato de efetuar a inscrição no concurso ser tido como "sair vitoriosa" da agência. Além da tentativa de dissuasão por um funcionário que a lembrou de "uma experiência com mulheres que não deu certo". Quando a trabalhadora já estava em exercício como carteira, a reportagem volta ao local de trabalho para saber da adaptação da jovem às atividades e descobre que "os moradores estão gostando. Eles dizem que a mulher é mais cuidadosa." Se as relações de gênero atuaram para dificultar a inscrição da jovem trabalhadora, mas não puderam impedi-la, elas continuaram a pressionar pelo reforço, como analisa Araújo (2004), de comportamentos definidos culturalmente como femininos, exemplificados no caso pela carteira ser "cuidadosa".

Um dos aspectos mais acionados para associar a atividade de carteiro ao universo masculino é a suposta necessidade de um adequado condicionamento físico. Na matéria, a candidata informa que é praticante de atividades físicas, o que a ajudaria a "enfrentar uma jornada de seis horas carregando uma mala de cartas de até 25 quilos", "ficar em pé" durante a jornada de trabalho, embora o seu medo estivesse centrado nas "condições climáticas adversas".

Trata-se de uma representação de gênero também observada em outros contextos de trabalho. Nesse sentido, em sua observação participante em uma empresa do setor calçadista em Portugal, Estanque $(2000,2005)$ constatou como a desigualdade de gênero perpassa desde a forma de inserção das mulheres nas atividades produtivas ao lugar que ocupam na hierarquia da empresa, sendo a força física, a "coragem" e a "capacidade de enfrentar a dureza da vida" elementos do imaginário masculino que reforçam a posição de dominação do homem no universo fabril.

Nas últimas seleções externas para o cargo de Agente de Correios nas atividades carteiro e operador de triagem, a avaliação do preparo físico dos candidatos e candidatas tem sido uma das etapas eliminatórios da seleção. Na seleção externa ocorrida em 2011, a Avaliação da Capacidade Física e Laboral dos candidatos foi realizada em parceria com o exército em todos os estados da Federação. A associação entre as duas instituições, 
além dos aspectos logísticos, também comporta aspectos simbólicos associados à força e à autoridade. Os testes físicos exigidos para homens e mulheres incluem corrida, barra fixa e dinamômetro (um aparelho que mede a força muscular dos candidatos nos ombros e costas). As exigências para cada sexo são ligeiramente distintas, o que não elimina o fator psicossocial associado à força e resistência física - características supostamente masculinas - dos testes.

No blog institucional dos Correios, alguns candidatos e candidatas questionaram e discutiram sobre as exigências da avaliação física na seleção realizada em 2011:

Ficou nítido que o público feminino não é bem-vindo nos Correios na função de carteiro, haja vista estabelecerem uma diferença insignificante entre homem e mulher no teste de Dinamômetro escapular (30kgf e $25 \mathrm{kgf}$, respectivamente, ou seja, apenas $5 \mathrm{~kg} f$ ). Será que a diferença de força muscular nesse caso é tão pequena? Em Santa Maria-RS, de cerca de 50 mulheres apenas 5 conseguiram atingir a marca (nem um $1 \mathrm{kgf}$ a mais), a maioria dos homens foram aprovados no Escapular. E com louvor, embora tivessem que atingir a marca de 30kgf. A imensa maioria fez de 35 a $45 \mathrm{kgf}$. Talvez esteja equivocada, mas está muito descarado (os números falam por si só). P.S. Obrigado por abrir esse espaço para comentário, sei que não vão publicá-lo. Todavia, estejam certos que tentarei expor minha opinião na maioria das redes de comunicação; em última instância, até a greve de fome recorrerei por essa tamanha falta de respeito com a MULHER. Estou chegando à conclusão que cometi um erro: SERÁ QUE COMETI O ERRO DE TER NASCIDO MULHER? [sic] (ELIANA, candidata) (TESTE..., 2011)

As intervenções prosseguiram e houve uma candidata favorável aos procedimentos adotados pela empresa, enquanto outras foram mais críticas:

Eliana, concordo com os testes físicos para o cargo de carteiro, e acho que realmente não pode haver muita diferença nos padrões de aferição entre homens e mulheres nesses testes, pois no serviço também não há. Existe apenas uma diferença de dois quilos a menos no limite de peso para a mulher carregar na bolsa que é diferente do homem, mas o serviço é a mesma coisa e o tempo de execução o mesmo. A empresa não está discriminando as mulheres com os testes, mas selecionando os candidatos de acordo com a realidade do serviço, que não é mais brando para a mulher. Existem excelentes carteiras nos correios, verdadeiras guerreiras [sic]. (ROSA, candidata) 
Rosa, não concordo com você, por eu ter sido reprovada no dinamômetro escapular pelo simples fato de eu não ter habilidade com o aparelho, haja vista que o mesmo não está disponível em nenhum lugar da minha cidade. E mais: todos os professores que eu perguntei, inclusive alguns especialistas no assunto, disseram que para se ter sucesso no resultado do dinamômetro escapular tem que ter alguma prática com ele. Outra coisa, como eu posso ser considerada sem preparo físico se consigo ficar pendurada na barra por mais de 25 segundos, faço 1800 metros em 10 minutos, consigo $33 \mathrm{~kg} f$ no dinamômetro manual, $82 \mathrm{kgf}$ no dinamômetro dorsal, e só não consegui os $25 \mathrm{kgf}$ no escapular? Outra coisa, segundo uma especialista em preparo físico, os testes de dinamômetro eram para ser os primeiros, pois requerem força muscular e depois de uma corrida de 12 minutos os seus músculos estão cansados e não é possível uma recuperação em apenas duas horas [sic]. (MERCILINE, candidata)

O teste físico de Dinamometria laboral é ilógico, pois mulheres dificilmente conseguem forçar os $25 \mathrm{~kg}$ pedidos. Acho que os correios deveriam desconsiderar este teste, mas de repente a intenção dos correios é que realmente não tenha mulher como carteiro. Alguém com influência deveria entrar nesta causa, pois nossa Presidente é mulher e capaz e este teste de dinamometria escapular não prova se alguém será capaz ou não [sic]. (PAULO, candidato)

Diante de toda a discussão, a resposta da empresa aos candidatos e candidatas foi expressa de maneira padronizada em diversos momentos nos seguintes termos:

As atividades rotineiras dos cargos de carteiro e operador de triagem e transbordo exigem que o profissional tenha condições físicas para desempenhar as tarefas do dia-a-dia [sic].

Os parâmetros da Avaliação da Capacidade Física e Laboral (ACFL) foram definidos após estudo médico. Os testes verificam o condicionamento aeróbico, a força, a flexibilidade, a potência muscular e a velocidade, que é o mínimo necessário para execução de tarefas funcionais e laborais destas atividades.

O candidato com desempenho insatisfatório apresenta pré-disposição para fadiga física e agravo de natureza osteomusculoligamentar. Tal avaliação é necessária em razão de que as atividades exigem força muscular [sic]. (TESTE..., 2011)

A polêmica envolvendo os testes físicos para a seleção das candidatas aos cargos operacionais atualizam as questões presentes desde 1992 e se 
apresentam como centrais para compreender a reduzida presença de mulheres na empresa: a suposta necessidade de um condicionamento físico.

No entanto, o peso da carga de trabalho manejada não atinge somente as mulheres, evidentemente, mas ambos os sexos. Em razão disso, desde a década de 1990 os sindicatos e a FENTECT têm pleiteado e conseguido diminuir a carga transportada manualmente pelos trabalhadores e trabalhadoras. Nesse sentido, por exemplo, em 1992 - quando as mulheres ingressaram na atividade de carteiro - o peso da bolsa desses trabalhadores era de 25 quilogramas. Depois de sucessivas negociações ao longo das últimas décadas, o acordo coletivo de 2009-2011 prevê 10 quilos para homens e 8 para mulheres, o que evidencia uma constante luta dos trabalhadores e trabalhadoras para um melhor redimensionamento da carga transportada como forma de preservar as condições de saúde de homens e mulheres.

Ao acompanhar as rotinas de trabalho nos CDDs pesquisados, foi possível constatar a representação das imagens de gênero que associam a atividade de carteiro a uma imagem masculinizada e à força. As brincadeiras entre carteiros sobre os distritos - uns mais "pesados" que os outros - suscita comentários acerca dos "distritos de mulher", isto é, os distritos que seriam menos pesados para atender às supostas fragilidades das trabalhadoras. São referências feitas - quase sempre por meio de brincadeiras - aos supostos benefícios que as mulheres teriam ao trabalhar em distritos supostamente mais fáceis, planos e com menos peso nas bolsas, o que alguns trabalhadores, em tom jocoso, chamam de "distritos de mulherzinha" ou "distritos de moça", mesmo quando não são trabalhadoras as responsáveis por eles.

Tais imagens de gênero não condizem com os depoimentos das carteiras sobre as suas rotinas:

[...] eu zero distrito que homem passou e não zerou.

(MARTA, nov. 2011)

Bom, no meu caso não tem diferença. Já fui motorizada e trabalhava de igual para igual ou até mais, carregando muito peso. Confesso, porém, que já ouvi muitas piadinhas, mas nunca dei ouvido. Concordo que a ECT precisa realmente dar uma atenção maior para nós mulheres, pois quando fiz o concurso 
parecia uma coisa, mas a realidade é outra. Não existe nenhum acompanhamento para saber se nós estamos de fato sendo respeitadas (peso, distrito e etc.).

(LILIA, nov. 2011)

$O$ meu setor [distrito] é bem pesado e tem um [carteiro] 'morcegando' em um setor bem mais leve. Enquanto eu me mato de trabalhar ele fica no bem bom. Acho que deveria haver redistritamento mais frequente para evitar essas injustiças.

(CAMILA, nov. 2011)

As experiências das trabalhadoras, apresentadas nos depoimentos, apontam para uma percepção das atividades de trabalho em suas rotinas como iguais ou até mais pesadas, o que contrasta com as imagens de gênero de trabalhadoras "frágeis", que ainda repercutem no cotidiano da área operacional dos Correios.

Trata-se da mesma imagem de gênero apresentada anteriormente pelo gestor do $\mathrm{CDD}$ onde a primeira carteira da região do $\mathrm{ABCD}$ foi lotada: para ele, os moradores aprovavam o trabalho dela por ela ser "mais cuidadosa" com as cartas. Evidentemente, tais imagens não são forjadas no espaço de trabalho da ECT, mas encontra condições para sua reprodução nas relações sociais de sexo vivenciadas no espaço de trabalho da estatal.

\section{Gênero e hierarquia funcional: considerações sobre a ascensão das mulheres}

Uma das consequências das imagens de gênero e das relações sociais de sexo que atribuem às mulheres uma inserção secundária no mercado de trabalho é a assimetria na hierarquia funcional de homens e mulheres. Por ser tratar de uma empresa pública, a política salarial é estabelecida para carreiras de forma a não contemplar parâmetros discricionários dos gestores e aspectos subjetivos, o que impede uma remuneração diferenciada para homens e mulheres que ocupam o mesmo lugar na carreira.

No entanto, a ascensão e ocupação de cargos de livre nomeação estão passíveis de influência das representações que perpetuam a ordem desigual de gênero. Assim, a política salarial pode revelar muito pouco sobre as relações de gênero na ECT, enquanto a distribuição sexual dos 
funcionários é capaz de mostrar como as relações sociais de sexo influenciam a ocupação de funções na estrutura da estatal.

Assim, vejamos na tabela 8 a distribuição de homens e mulheres nas funções e atividades gratificadas da ECT:

TABELA 8 - POSIÇÃO DE HOMENS E MULHERES OCUPANTES DE FUNÇÕES (MAIO DE 2010)

\begin{tabular}{|c|c|c|c|c|c|c|}
\hline \multirow{2}{*}{$\begin{array}{l}\text { Tipo de Função } \\
\text { Apoio Operacional/ Técnico }\end{array}$} & \multicolumn{2}{|c|}{ Mulheres } & \multicolumn{2}{|c|}{ Homens } & \multirow{2}{*}{$\begin{array}{l}\text { Total com } \\
\text { Função } \\
2.983\end{array}$} & \multirow{2}{*}{$\begin{array}{l}\begin{array}{l}\text { Percentual } \\
\text { do Efetivo }\end{array} \\
2,7 \%\end{array}$} \\
\hline & 782 & $26,22 \%$ & 2.201 & $73,78 \%$ & & \\
\hline Atividade Especial & 6.216 & $22,19 \%$ & 21.797 & $77,81 \%$ & 28.013 & $25,8 \%$ \\
\hline Confiança & 4.618 & $32,28 \%$ & 9.689 & $67,72 \%$ & 14.307 & $13,18 \%$ \\
\hline Gerencial & 391 & $20,27 \%$ & 1.538 & $79,73 \%$ & 1.929 & $1,77 \%$ \\
\hline Gratificada & 702 & $45,85 \%$ & 829 & 54,15 & 1.531 & $1.41 \%$ \\
\hline Técnica & 872 & $47,26 \%$ & 973 & $52,74 \%$ & 1.845 & $1,7 \%$ \\
\hline Total & 13.581 & $26,83 \%$ & 37.027 & $73,17 \%$ & 50.608 & $46,6 \%$ \\
\hline
\end{tabular}

Fonte: Elaborado pelo autor.

A tabela 8 mostra que cerca de $22 \%$ das mulheres são contempladas com funções consideradas "atividades especiais". Todavia, como discutido, as atividades especiais não representam uma ascensão na carreira das trabalhadoras e trabalhadores. Contudo, apesar de não representar uma ascensão funcional, as atividades especiais implicam em um acréscimo salarial importante para os ocupantes de cargos de nível médio. Além disso, atividades motorizadas estão associadas às características masculinas, o que tem pautado a luta das trabalhadoras para que tenham acesso às atividades especiais, como foi reiterado no acordo coletivo de 2009-2011, de maneira a garantir o "direito de igualdade na seleção para exercer a função motorizada".

Ao se analisar a distribuição de funções às trabalhadoras, verifica-se que as mulheres ocupavam quase $27 \%$ das funções, isto é, eram 13.581 trabalhadoras com função. Se considerarmos que eram 18.968 no total, há aí mais de $71 \%$ de mulheres contempladas com funções e atividades com gratificação, enquanto entre os homens o percentual era de $51 \%$. No entanto, é preciso eliminar o percentual considerado de apoio técnico e apoio operacional, bem como os dados sobre atividades especiais. Isso porque as primeiras abarcam um leque de atividades bastante variado na 
hierarquia da empresa, enquanto as atividades especiais não configuram processos de ascensão.

Com esse recorte, são consideradas na análise 48,5\% das mulheres com função na empresa que podem ter ascendido ou progredido na carreira. Averígua-se, pelos dados da tabela 8 , que nas funções de confiança há a representatividade de $32,28 \%$ de mulheres, enquanto na função gerencial o percentual é de 20,27\%. As funções técnicas, todavia, contam com o representativo percentual de $47,26 \%$ de mulheres, embora isso represente apenas 872 funcionárias em um universo de 108.516.

Por todos os ângulos, portanto, seja na estrutura hierárquica ou no "chão de fábrica", constata-se a ínfima participação das mulheres na força de trabalho dos Correios. De forma geral, portanto, as mulheres são contempladas com funções e atividades gratificadas na mesma proporção em que estão representadas na empresa.

Diante desse quadro, a ECT não ficou alheia ao Programa Pró-Equidade de Gênero da Secretaria de Políticas para Mulheres da presidência da República. A estatal iniciou a adesão ao programa em novembro de 2011 com o intuito de melhorar as condições de inserção das mulheres. Como parte da adesão ao Programa, a empresa apresentou dados à Secretaria de Políticas para Mulheres que ajudam a detalhar o perfil da força de trabalho da empresa.

Nesse perfil da força de trabalho, a ECT informa que em 31 de dezembro de 2011 não havia nenhuma mulher ocupando cargos na alta direção da empresa. Em 2012, no entanto, houve pela primeira vez a nomeação de uma mulher para ocupar um cargo na cúpula da ECT. Além disso, entre os vinte e oito diretores regionais, há duas mulheres - o que não deixa de ser uma vitória. Segundo a estatal, durante o ano de 2011 houve a promoção de 118 mulheres e 310 homens a cargos de gerência e diretoria, isto é, a proporção de mulheres promovidas em relação aos homens foi de uma em cada três. Comparando com a baixa representatividade das mulheres na empresa, trata-se de um sinal de que as mulheres têm obtido vagarosamente a ascensão na estrutura da empresa.

Apesar da ascensão de poucas mulheres e da baixa presença feminina, a ECT não havia realizado nenhum estudo próprio para averiguar 
os possíveis fatores impeditivos à promoção das mulheres. Com isso, a empresa, até o momento de adesão ao programa, também não havia implantado nenhuma política de incentivo à equidade de gênero. A lógica da empresa se fundamenta em uma suposta objetividade e cientificidade dos critérios de ascensão e promoção aferidos pelo PCCS e pelas ferramentas de gestão de pessoas. Evidentemente, tais mecanismos impedem a percepção do problema ao apontarem critérios supostamente objetivos que dificultariam a ascensão das mulheres. A estatal, com isso, reitera a sua omissão quanto às questões de gênero: no início da década de 1990, a empresa não estimulou diretamente a presença de mulheres em sua força de trabalho operacional; até o momento, também tem deixado de promover a ascensão das trabalhadoras por basearem-se em ferramentas gerenciais supostamente neutras.

Aliás, criar e integrar aos instrumentos de gestão de pessoas questões de gênero é o objetivo do Programa Pró-Equidade de Gênero, do qual resultou o I Fórum dos Direitos Humanos e da Igualdade de Gênero e Raça nos Correios, ocorrido em 2011, no qual questões pertinentes aos temas foram apresentadas e oficinas para debate e formulação de propostas foram realizadas. Os resultados desses esforços iniciais, contudo, ainda não são visíveis para os trabalhadores e trabalhadoras da estatal.

\section{As "questões da mulher" nas reivindicações sindicais}

Quais são as conquistas e reivindicações dos sindicatos ecetistas nas últimas duas décadas que perpassam as questões de gênero?

A pauta de reivindicações da FENTECT para as negociações coletivas de 2009-2010 contemplou uma seção específica para as mulheres, denominada "Questão da Mulher". Baseada no histórico de negociações e nos acordos já estabelecidos com a empresa, a pauta propunha um avanço em algumas cláusulas. Assim, por exemplo, reivindicava a criação de uma comissão em cada diretoria regional com a participação sindical para apurar as denúncias de assédio moral e sexual e discriminação, bem como a demissão por justa causa do autor e posterior encaminhamento do caso à justiça. Todavia, o que a entidade sindical conquistou foi o compromisso 
da ECT em combater tais práticas, promover cursos e palestras e a necessidade de encaminhamento das denúncias para a diretoria regional para que fossem apuradas.

A FENTECT propôs ainda que a ECT disponibilizasse equipe multiprofissional para atendimento das trabalhadoras vítimas de violência doméstica, bem como a prestação de auxílios necessários à sua integridade física e psicológica, além da participação em campanhas públicas sobre o tema. Sobre isso, no entanto, não houve avanço e nada foi incluído no acordo.

O quadro 8, apresentado a seguir, compara as reivindicações com viés de gênero e as conquistas no acordo coletivo:

\section{QUADRO 8-REIVINDICAÇÕES E CONQUISTAS DAS TRABALHADORAS}

\begin{tabular}{|c|c|}
\hline $\begin{array}{l}\text { Condições de trabalho da mulher (sic) } \\
\text { O peso máximo para as empregadas } \\
\text { movimentarem e transportarem } \\
\text { não poderá ser superior a } 5 \mathrm{~kg} \text {. } \\
\text { Banheiros femininos e fornecimento de } \\
\text { uniforme diferenciada [sic] e garantia à } \\
\text { empregada de exercer a função motorizada } \\
\text { [...] sem qualquer tipo de discriminação. }\end{array}$ & $\begin{array}{l}\text { Distribuição Domiciliária e Garantias às Empregadas } \\
\text { O limite de peso transportado pelo carteiro será } \\
\text { de } 10 \text { kg para homem e } 8 \text { kg para a mulher. } \\
\text { As funcionárias que estiverem grávidas } \\
\text { poderão ter uma mudança provisória de suas } \\
\text { atividades de trabalho, desde que homologado } \\
\text { pelo serviço médico da empresa. } \\
\text { Banheiro feminino com ducha higiênica } \\
\text { em todas as edificações. } \\
\text { A ECT concederá às empregadas a prorrogação } \\
\text { por } 60 \text { dias da licença-maternidade, } \\
\text { conforme estabelece a Lei 11.770. } \\
\text { Igualdade na seleção para exercer a função motorizada. } \\
\text { A ECT assegurará à empregada, durante a jornada } \\
\text { de trabalho de oito horas, um descanso especial } \\
\text { de duas horas ou dois descansos de uma hora } \\
\text { para amamentar o próprio filho, até que este } \\
\text { complete um ano de idade, podendo a jornada } \\
\text { de trabalho ser reduzida para seis horas. } \\
\text { As empregadas da ECT, mesmo quando se } \\
\text { encontrarem em licença médica, farão jus ao } \\
\text { pagamento de reembolso-creche até o final do ano } \\
\text { em que seu filho, tutelado ou menor sob guarda em } \\
\text { processo de adoção, atingir o sétimo aniversário. }\end{array}$ \\
\hline
\end{tabular}

Fonte: Pauta de Reivindicação e Acordo Coletivo 2009 - 2011.

A maior parte das questões versa sobre as condições maternas das trabalhadoras, como se verifica no quadro. Sem deixar de reconhecer a 
importância de tais pleitos, sobretudo ao se relembrar que no acordo coletivo de 1995 as trabalhadoras conquistaram pela primeira vez uma cláusula garantindo o direito de amamentar o filho durante o expediente de trabalho, percebe-se que as reivindicações reiteram as imagens de gênero que associam o papel da mulher trabalhadora à figura abstrata de "mãe", reafirmada pela empresa e também pelos sindicatos.

O auxílio-creche e babá que as trabalhadoras conquistaram ainda na década de 1990 representam, no entanto, uma ruptura com a ordem de gênero ao garantir às mulheres ecetistas condições de manterem seus filhos que tenham até sete anos de idade em creches durante o expediente de trabalho. Assim, há o reconhecimento de que as trabalhadoras exercem uma atividade profissional e, para o seu bom desempenho e livre exercício de sua cidadania, ter condições de pagar uma creche é fundamental. $\mathrm{O}$ valor do benefício, reajustado anualmente, representa quase a metade do salário básico de Agentes de Correios: R \$ 360,20, em dezembro de 2010.

Todavia, deve-se registrar que há uma reivindicação - e mesmo uma polêmica - entre trabalhadores, que gostariam de receber o benefício. Homens só o recebem em casos especiais, ou seja, se for viúvo, pai solteiro ou separado com a guarda do filho. Em razão disso, são poucos os que têm acesso ao benefício. Em dezembro de 2010, por exemplo, eram $2.399 \mathrm{mu}$ lheres e 23 homens. Sendo assim, uma reivindicação dos trabalhadores é também receber o auxílio. A queixa mais ouvida entre os trabalhadores é que "as mulheres não têm filhos sozinhas", o que expressa como as representações de gênero na empresa ainda atribuem somente à mulher a responsabilidade pelo cuidado dos filhos.

Outra reivindicação presente na pauta de reivindicações das trabalhadoras versava sobre a "participação da mulher nas decisões da empresa". Para isso, pleiteava-se a inclusão de uma cláusula que obrigasse a "ECT a implementar, em parceria com a Secretaria da Mulher da FENTECT, ação afirmativa visando à valorização da mulher”. No acordo 2009-2011, contudo, não houve a inclusão de tal compromisso no acordo coletivo. Na pauta 2011-2012, a FENTECT propôs também a adesão da ECT ao Programa Pró-Equidade de Gênero, decisão da empresa que já havia sido tomada antes da reivindicação. Neste item, portanto, a reivindicação foi extemporânea, 
com a empresa adiantando-se à demanda sindical. A decisão da empresa e a reivindicação sindical, no entanto, mostram, pelo menos, o reconhecimento da necessidade de medidas para melhor inclusão, permanência e ascensão das mulheres na estatal.

\section{CONSIDERAÇÕES FINAIS}

Ao analisar a força de trabalho na ECT, constata-se a crescente incorporação de trabalhadores ao quadro, mostrando que o setor demanda a contínua incorporação de trabalhadores, o que é bastante divergente da tendência internacional de redução do número de empregos no setor. Nessa direção, nem mesmo o processo de automação da triagem em Centros Operacionais de Tratamento de Cartas e Encomendas levou à redução do número de trabalhadores.

Todavia, o número de carteiros ainda está aquém do necessário, como evidencia a crescente terceirização da atividade de distribuição a partir de meados dos anos 2000. A FENTECT, contudo, obteve uma vitória parcial contra as terceirizações ao acionar a Justiça do Trabalho, já que o Tribunal Superior do Trabalho considerou a prática nas áreas finalísticas da ECT ilícita. No entanto, ainda não é uma decisão final, estando em disputa, principalmente, a definição de "atividades finalísticas" da ECT.

A implantação do novo plano de carreiras, cargos e salários em 2008 foi marcada por disputas entre a FENTECT e a direção da estatal. Os sindicalistas obtiveram importante vitória contra a criação do "cargo amplo". Com isso, as atividades de trabalho continuam a orientar o desenho dos cargos. Além disso, houve um avanço também para os trabalhadores no que concerne à possibilidade de Agentes de Correios ascenderem na estrutura hierárquica da empresa. Isso, no entanto, ainda carece de regulamentação e critérios objetivos no processo seletivo para se concretizar, minimizando aspectos subjetivos e políticos.

Contudo, o embate em torno do PCCS teve um desdobrando judicial, levando algumas das definições para o âmbito da Justiça do Trabalho, fazendo com que somente em 2011 houvesse uma definição de alguns pontos. 
$\mathrm{O}$ que se depreende das frequentes mediações judiciais entre sindicalistas e diretores dos Correios é um crescente processo de judicialização das políticas de gestão do trabalho, o que inclui também julgamentos de dissídios coletivos e, consequentemente, a definição da política salarial da categoria.

A política salarial e de benefícios dos Correios é uma ferramenta utilizada para obtenção do consentimento dos trabalhadores. Apesar dos baixos salários pagos aos funcionários em início de carreira, a relativa estabilidade funcional e os benefícios são apontados pelos trabalhadores como elementos que justificam a submissão às características do trabalho. Isso, contudo, não diminui as críticas dos trabalhadores à amplitude da faixa salarial, sobretudo quando cargos operacionais e administrativos são comparados. A separação entre cargos e áreas da ECT também é reforçada, assim, pela estrutura remuneratória.

Ao discutir a política de gestão de pessoas nos Correios a partir de um recorte de gênero, observa-se que a força de trabalho da empresa é majoritariamente masculina. Isso decorre da imagem de gênero que associa as atividades de trabalho na empresa a atributos supostamente masculinos, como força física e condicionamento corporal para suportar o peso da carga transportada e intempéries durante a jornada de trabalho.

Entre os trabalhadores, a jocosidade entre homens acerca de supostas facilidades que as mulheres teriam por sua suposta fragilidade contrasta com os depoimentos das trabalhadoras, que afirmam realizar atividades iguais. Trata-se, assim, de compreender que as imagens de gênero que atribuem ao trabalho feminino um lugar secundário continuam a operar entre os trabalhadores, reiterando as desigualdades de gênero no interior da estatal.

A imagem é reiterada não só entre os trabalhadores. Sindicalistas, a despeito do discurso a favor da equidade de gênero, evidenciam suas percepções sobre as relações de gênero quando denominam pontos da pauta de reivindicações de "questões da mulher", sendo a maior parte das reivindicações - elaboradas por homens - reiterações das imagens de gênero que associam as trabalhadoras à figura abstrata de "mãe", reforçando relações de sexo que atribuem à inserção profissional da mulher no mercado 
de trabalho um papel secundário. A qualificação do tema no âmbito sindical, portanto, é premente.

Isso se reflete na baixa presença de mulheres em posições de comando na estatal, refletindo também o pequeno percentual feminino na força de trabalho.

Ao aderir ao Programa Pró-Equidade de Gênero, os diretores dos Correios reconhecem a necessidade de implantar políticas de gestão que melhorem as condições de acesso, permanência e promoção das trabalhadoras na hierarquia profissional. Contudo, as ações iniciadas ainda são incipientes, não alterando o quadro apresentado.

Por fim, cabe destacar que houve um trânsito de sindicalistas para a estrutura gerencial da empresa. Tal fato, marcado pela proximidade ideológica e partidária entre governo e sindicalistas, tem resultado no aumento da desconfiança dos trabalhadores em relação aos interesses dos sindicalistas. Contudo, apesar da proximidade entre gestores e sindicalistas, os anos 2000 foram marcados por movimentos grevistas anuais dos trabalhadores dos Correios, mostrando que há uma insatisfação permanente em relação às condições de trabalho, às políticas de gestão e às relações de trabalho. 